\title{
Estradiol Signaling at the Heart of Folliculogenesis: Its Potential Deregulation in Human Ovarian Pathologies
}

\author{
Stéphanie Chauvin * ${ }^{\mathbb{C}}$, Joëlle Cohen-Tannoudji and Céline J. Guigon
}

Citation: Chauvin, S.;

Cohen-Tannoudji, J.; Guigon, C.J.

Estradiol Signaling at the Heart of

Folliculogenesis: Its Potential

Deregulation in Human Ovarian

Pathologies. Int. J. Mol. Sci. 2022, 23,

512. https://doi.org/10.3390/

ijms23010512

Academic Editor: Farzad Pakdel

Received: 23 November 2021

Accepted: 24 December 2021

Published: 3 January 2022

Publisher's Note: MDPI stays neutral with regard to jurisdictional claims in published maps and institutional affiliations.

Copyright: (C) 2022 by the authors. Licensee MDPI, Basel, Switzerland. This article is an open access article distributed under the terms and conditions of the Creative Commons Attribution (CC BY) license (https:// creativecommons.org/licenses/by/ $4.0 /)$.
BFA, UMR 8251, CNRS, ERL U1133, Inserm, Université de Paris, F-75013 Paris, France; joelle.cohen-tannoudji@u-paris.fr (J.C.-T.); celine.guigon@univ-paris-diderot.fr (C.J.G.)

* Correspondence: stephanie.chauvin@inserm.fr; Tel.: +33-157278408

\begin{abstract}
Estradiol (E2) is a major hormone controlling women fertility, in particular folliculogenesis. This steroid, which is locally produced by granulosa cells (GC) within ovarian follicles, controls the development and selection of dominant preovulatory follicles. E2 effects rely on a complex set of nuclear and extra-nuclear signal transduction pathways principally triggered by its nuclear receptors, $\mathrm{ER} \alpha$ and ER $\beta$. These transcription factors are differentially expressed within follicles, with ER $\beta$ being the predominant ER in GC. Several ER $\beta$ splice isoforms have been identified and display specific structural features, which greatly complicates the nature of ER $\beta$-mediated E2 signaling. This review aims at providing a concise overview of the main actions of E2 during follicular growth, maturation, and selection in human. It also describes the current understanding of the various roles of ER $\beta$ splice isoforms, especially their influence on cell fate. We finally discuss how E2 signaling deregulation could participate in two ovarian pathogeneses characterized by either a follicular arrest, as in polycystic ovary syndrome, or an excess of GC survival and proliferation, leading to granulosa cell tumors. This review emphasizes the need for further research to better understand the molecular basis of E2 signaling throughout folliculogenesis and to improve the efficiency of ovarian-related disease therapies.
\end{abstract}

Keywords: estradiol; estrogen receptors isoforms; granulosa cells; folliculogenesis; polycystic ovary syndrome; granulosa cell tumors

\section{Introduction}

Estradiol (E2) is a steroid hormone that regulates important events occurring during the normal menstrual cycle in women, especially the sequence of ovarian follicle growth and maturation. During the different waves of follicular development, one antral follicle is selected for maturation until ovulation, while subordinate follicles inevitably enter atresia [1,2]. E2 is specifically secreted by the granulosa cells (GC) of developing antral follicles upon follicle-stimulating hormone (FSH) stimulation to strengthen follicular growth and maturation. The increased concentration of E2 contained in the follicular fluid of larger follicles further participates in the selection of a dominant preovulatory follicle [3] and finally triggers the luteinizing hormone ( $\mathrm{LH}$ ) surge required for ovulation [1]. As a result of these major intra-ovarian activities, E2 is considered as an important marker of follicle quality.

E2 mediates its effects principally through the activation of $\operatorname{ER} \alpha$ and $\operatorname{ER} \beta$ receptors that are members of the superfamily of ligand-activated transcription factors [4]. Both receptors act mainly in the nucleus to regulate gene transcription through direct (on putative estrogen response element sequences, ERE) or indirect (though tethering to other transcription factors) DNA interactions. This genomic signaling is further augmented by the non-genomic GPER1 (also known as GPR30 or GPER), which is a membrane-bound G-protein-coupled receptor capable of mediating both rapid and transcriptional events in response to high levels of E2 [5]. 
Based on the well-established importance of E2 in follicular development and maturation, the current review aims at highlighting the potential role of E2 signaling in two human ovarian pathologies that still need better treatment strategies, such as polycystic ovary syndrome (PCOS) and granulosa cell tumors (GCT). This review gives a special emphasis to the recent advances in the biology of ER $\beta$ signaling and to the possible contribution of its different isoforms in those pathologies.

\section{Estrogen Signaling Is Critical for Human Follicle Quality}

Follicle quality relies on the proper growth and maturation of GC that implicate the action of endocrine factors such as gonadotropins and E2. Although the prominent role of E2 in folliculogenesis is now established, its downstream signaling is still unsolved, principally because of a lack of information on the expression of its different receptors (at either mRNA or proteins levels) in human GC of different follicle sizes. Yet, a few immunohistochemical studies in human and non-human primate ovaries reveal a differential expression of $\mathrm{ER} \alpha$ and $\mathrm{ER} \beta$ within the GC of developing follicles; in pre-antral follicles, $\mathrm{ER} \beta$ but not $\mathrm{ER} \alpha$ is detectable, while in mature follicles, both receptors are expressed $[6,7]$. Then, ER $\beta$ would arise as the main mediator of E2 actions in GC.

\subsection{Human Estrogen Receptors Exist in Multiple Isoforms}

$E R \alpha$ and $E R \beta$ are encoded by two distinct genes (ESR1 and ESR2, respectively), and the mature transcripts contain eight exons. Similarly to other receptors belonging to the nuclear receptor superfamily, these two receptors are composed of a variable N-terminal transactivation domain (that of $\mathrm{ER} \beta$ is shorter than that of $\mathrm{ER} \alpha$ ), a highly conserved DNAbinding domain (DBD), and a C-terminal ligand-binding domain. Many alternatively spliced transcripts for $\operatorname{ER} \alpha$ and $E R \beta$ have been identified, but a few have been shown to translate to functional protein products $[4,8]$. ER $\alpha$ exists in three isoforms: a full-length $66 \mathrm{kDa}$ isoform $(\mathrm{ER} \alpha 66)$ containing 595 amino acids, and two truncated isoforms of 46 $(\mathrm{ER} \alpha 46)$ and $36 \mathrm{kDa}(\mathrm{ER} \alpha 36)$ with 421 and 279 amino acids, respectively. ER $\alpha 46$ lacks the transactivation domain AF-1 located in the N-terminal region, while ER $\alpha 36$ lacks both transactivation domains AF-1 and AF-2 (within the C-terminal domain) but retains the DBD and a partial ligand-binding domain (presence of an extra 27-amino acid sequence in its C-terminal region) [9]. ER $\alpha 46$ arises from alternative splicing of the ESR1 gene from exon 2 [10], alternative translation initiation [11,12], or by proteolysis of the native $\mathrm{ER} \alpha 66$ [13]. ER $\alpha 46$ and $\mathrm{ER} \alpha 36$ both inhibit the transcriptional activity of ER $\alpha 66[9,10]$. These shorter ER $\alpha$ isoforms mediate rapid estrogen signaling and inhibit the genomic activity of ER $\alpha 66$ by competing with DNA binding sites [9] or by reducing ER $\alpha 66$ AF-1 activity [14]. Although ER $\alpha 66$ expression has been widely demonstrated in the human ovary, that of ER $\alpha 46$ and ER $\alpha 36$ remains unknown.

Unlike rodent ER $\beta$ spliced isoforms, which include insertions or deletions throughout the middle region of the proteins, human $\mathrm{ER} \beta$ spliced isoforms $(\mathrm{ER} \beta 1, \mathrm{ER} \beta 2, \mathrm{ER} \beta 3, \mathrm{ER} \beta 4$, and $E R \beta 5$ ) arise from the specific alternative splicing of exon 8 , thereby resulting in sequence variations or truncations at the C-terminal region of the protein [15] (Figure 1). All these isoforms are differently expressed in multiple human tissues as well as in a variety of human cell lines, except for ER $\beta 3$, which is selectively expressed in the human testis $[16,17]$. Alternative splicing for both ESR1 and ESR2 genes is species-specific, limiting the relevance of rodent models in the study of the impact of variant isoforms on tissue responsiveness to E2. Indeed, the ER $\beta 2$ isoform described in rodents contains in-frame insertions of unique peptide sequence within the ligand-binding domain, resulting in reduced but still detectable ligand-binding capacity [18]. By contrast, alternative splicing in the C-terminal of ESR2 in humans and primates [19] leads to ER $\beta$ isoforms unable to bind E2 [20]. Different studies show that ER $\beta 2, E R \beta 4$, and ER $\beta 5$ spliced isoforms cannot form homodimers and bind ligand because of the missing coactivator recruiting helix 12 [20-22]. Therefore, the longest $E R \beta 1$ isoform is the unique fully active ER $\beta$ that binds $E 2$. However, the binding affinity of $E R \beta 1$ to $E 2$ is approximately half that of $E R \alpha$ [23], and ER $\beta 1$ homodimers show less 
potent activity on the consensus ERE than ER $\alpha$ homodimers [24]. ER $\beta 2$, ER $\beta 4$, and ER $\beta 5$ have no ligand-dependent transcriptional activity but can heterodimerize with ER $\beta 1$ and enhance its E2-mediated transcriptional activity [20]. Their propensity to dimerize in vitro follows the descending order of ER $\beta 1-\beta 4 \geq \beta 1-\beta 5>\beta 1-\beta 1>\beta 1-\beta 2$ [20]. In addition, all $E R \beta$ isoforms inhibit the transcriptional activity of ER $\alpha$ on an ERE-containing promoter but with various efficiencies (ER $\beta 1>E R \beta 2>E R \beta 5$ ) [22]. Strikingly, ER $\beta 2$ preferentially forms a heterodimer with $E R \alpha$ rather than with $E R \beta$ [25] and elicits a dominant negative effect on ER $\alpha$-mediated transactivation [25] by targeting the heterodimers to the proteasome [26]. $E R \beta 1, E R \beta 2$, ER $\beta 4$, and ER $\beta 5$ can also promote ligand-independent activity, which is consistent with their intact $\mathrm{N}$-terminal transactivation regions [21,27].

Coding region

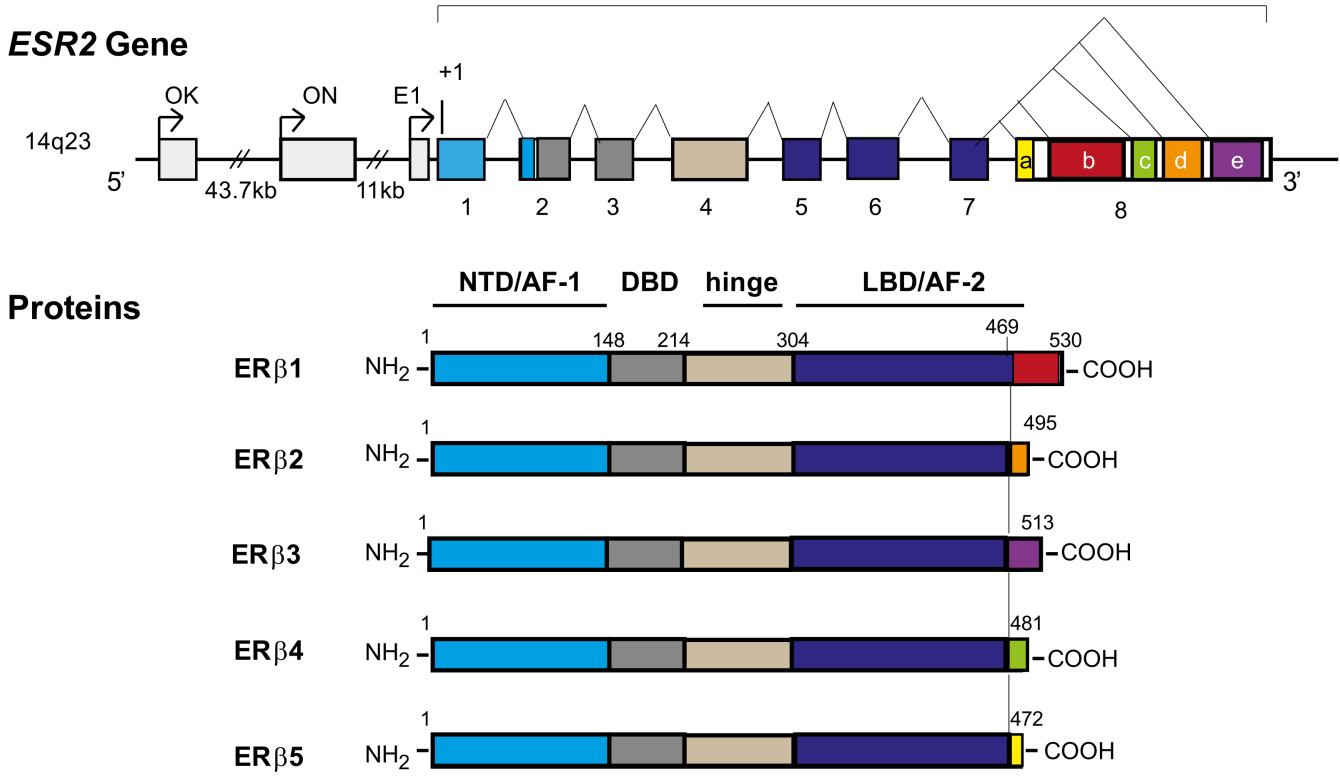

Figure 1. Schematic representation of ESR2 gene and human ER $\beta$ protein isoforms (ER $\beta 1-5)$. Within the $5^{\prime}$ untranslated region of ESR2, three distinct promoters are found (OK, ON, and E1). Exons 1-8 are represented by boxes, and the introns are represented by lines. Exons are represented in different colors, and their encoding protein domains are represented by the corresponding colors. The use of alternative acceptor sites leads to the production of five different proteins (ER $\beta 1, E R \beta 2$, $\mathrm{ER} \beta 3$, ER $\beta 4$, and ER $\beta 5$ ). All these isoforms share common exons 1-7 but differ in their alternative exon 8 (b, d, e, c, and a respectively). For protein isoforms, from the N-terminus to C-terminus, the N-terminal domain (NTD)/activation function 1 (AF-1) is colored in blue, the DNA binding domain (DBD) is colored in dark gray, the hinge domain is colored in clear brown, and the ligand-binding domain (LBD)/activation function 2 (AF-2) is colored in dark blue. At the end of the protein, the alternative splicing produces proteins identical in their first 468 amino acids but differing in the sequence corresponding to the end of the ligand binding of ER $\beta 1$, which modifies their capacity to bind ligands. Numbers indicate the amino acids of the protein.

In primate and human ovaries, ER $\alpha$ is diffusely expressed in thecal, interstitial, and in the GC of antral follicles, while ER $\beta$ is predominantly located in GC. ER $\beta$ expression begins in the GC of immature follicles and reaches maximum levels in maturing and preovulatory follicles $[6,28]$. Analyses of ER $\beta$ isoform mRNA in human also show that all ER $\beta$ isoforms are expressed in the ovary [29], in GC [6,30], as well as in various forms of ovarian cancers [31,32], including GC tumors [33]. In addition, ER $\beta 1$ and ER $\beta 2$ mRNA are differently expressed across the luteal phase with a maximal expression observed in the mid-luteal phase for ER $\beta 1$ and in the early luteal phase for ER $\beta 2$ [34].

The precise molecular mechanisms regulating ER $\beta$ alternative splicing are largely unknown. Still, E2 is described to specifically up-regulate the expression of ER $\beta 4$ and 
ER $\beta 5$ mRNA in human GC of antral follicles [30]. ER $\beta$ originates from multiple putative promoters $\left(5^{\prime}\right.$-untranslated first exons $0 \mathrm{~K}, 0 \mathrm{~N}$, and E1) $[35,36]$ with the same final transcript (Figure 1). mRNAs for each ER $\beta$ isoform have different and cell-type specific proportions of the three $5^{\prime}$-untranslated regions ( $5^{\prime}$-UTRs) that determine their translational efficiencies [37]. These $5^{\prime}$-UTRs may be affected by methylation on GC-rich regions within the promoter [38,39]. Interestingly, the various ER $\beta 5^{\prime}$-UTRs determine a differential and cell-specific translation inhibition of ER $\beta$ expression (0K promoter activation generally possesses a greater inhibitory effect [36]) through various mechanisms such as ribosome stalling or increased mRNA instability [40]. In addition, Smith et al. describe a crosstalk between multiple $5^{\prime}$ - and $3^{\prime}$-UTRs in the differential regulation of translation of the different $\mathrm{ER} \beta$ isoforms [36].

Collectively, these data underline the high complexity and cell specificity in the regulation of ER $\beta$ isoform expression that might play important roles in E2 signaling.

\subsection{Mechanisms of Action of ER}

The specificity of E2 action varies depending on the ER distribution pattern in target tissues that express various sets of co-regulators. Several reviews have extensively described how ER can act both in the nucleus and in the cytosol, in the presence or in the absence of E2 [15,41-46]. These reviews also provide information on how ER activities can be influenced by several post-translational modifications that can occur in the absence of ligand [47-49]. Multiple studies also gave precision on ER genomic activities and showed that homo- or heterodimers involving ER $\beta$ and ER $\alpha$ have significantly different target genes [48,50-52]. Genomic studies revealed that only one-third of the E2-responsive genes identified so far contain sequences in their promoter that resemble ERE $[53,54]$. Ligand-bound ER can also regulate gene transcription without directly binding to DNA through protein-protein interactions with other DNA-binding transcription factors such as Jun/Fos (at AP-1 response elements) [55] or SP-1 (at GC-rich SP-1 motifs) or by interaction with the nuclear factor kappa B (NFKB) pathway [56]. Strikingly, ER $\beta$ possesses a higher ligand-independent activity than $\mathrm{ER} \alpha$, with genomic binding sites containing AP-1-like binding regions associated with ERE-like sites $[45,52,54]$; ER $\beta$ preferentially binds to AP-1 rather than ERE sites. Therefore, in the absence of E2, ER $\beta$ would be able to regulate gene expression through non-classical binding sites such as AP-1, while in E2-dominated environment, ER $\beta$ may switch over to ERE-based transcription to control the expression of other genes [45]. ER $\beta 1, E R \beta 2$, ER $\beta 4$, and ER $\beta 5$ also appear to have constitutive transcriptional activity largely independent of E2 binding [4], which adds another layer of complexity in ER $\beta$-mediated signaling.

In addition to its wide genomic effects, E2 is also able to exert non-genomic activities mediated by membrane-associated ER triggering both PI3K and MAPK signaling pathways activation, thereby promoting indirect changes in gene expression [44]. ER proximity to membranes also facilitates interactions with other membrane-associated proteins such as G-proteins, various membrane receptors (e.g., insulin growth factor or epidermal growth factor receptors), or signaling molecules (e.g., Src or PI3 kinase) that initiate crosstalk between ER and other signaling pathways [44].

\subsection{Role of E2 Signaling in Follicular Growth, Differentiation, and Atresia}

Multiple studies demonstrated that during folliculogenesis, ovarian follicles undergo several stages of development and maturation before ovulation. The success of folliculogenesis depends on the action of important regulators, such as locally produced ovariansecreted growth factors and FSH [57]. Specifically, during antral follicle development, FSH acts on GC to stimulate the expression of the aromatase (CYP19A1), which converts thecal-derived C19 androgens to C18 estrogens, principally E2. E2 synergizes with FSH to up-regulate the expression of steroidogenic enzymes and to stimulate GC proliferation and maturation (i.e., by inducing LH receptor (LHR) expression) [58]. Finally, the increased concentration of E2 present in the follicular fluid of large antral follicles participates in the 
selection of dominant preovulatory follicles and triggers the LH surge necessary to terminate the follicular program and to induce ovulation [58]. Most follicles ( $>99.9 \%$ of follicles) do not reach the ovulatory stage but instead become atretic because of the apoptosis of the GC layer $[1,2,58]$.

Whilst the importance of E2 in follicle development is well established, the role of ER in GC biology remains incompletely understood, particularly in human. However, valuable clues can be provided by transgenic mouse models even if human ER $\beta$ isoforms are not conserved in rodents. In mice, the deletion of either ER induces various ovarian phenotypes, from subfertility (Esr2 $2^{-/-}$mice) due to the disrupted growth and maturation of antral follicles leading to reduced ovulation rate to infertility due to the development of cystic follicles and anovulation (Esr1 ${ }^{-/-}$mice); in the case of $E R \alpha$, this effect on the ovary would be mainly indirect, via its regulation of pituitary gonadotropins, whereas ER $\beta$ deletion would impair directly GC proliferation and maturation [59-62]. In addition, E2 is depicted to prevent GC apoptosis in rodents and cattle [63] and to promote cell cycle progression [64] by regulating Bcl-2, cyclin D, and cyclin E expression [65]. By contrast, in human and primate, E2 possesses intra-follicular atretogenic effects on dominant preovulatory follicles, which can be reversed or not by FSH, depending on the study $[3,66]$. The observed E2induced GC apoptosis may be the result of activation of different ER subtypes, especially $E R \beta$ isoforms [67-70]. Indeed, various studies reveal differential effects of ER $\beta$ isoforms on cell proliferation and/or apoptosis, such as ER $\beta 2$ and ER $\beta 5$ that increase prostate or glioma tumor proliferation [68,71], while ER $\beta 1$ and ER $\beta 4$ induce GC apoptosis [30].

In human, ovulatory defects have been linked to RsaI and AluI polymorphisms in ESR2 [72]. These polymorphisms do not result in a change in the amino acid sequence of ER $\beta$ protein, but the translation rates or mRNA half-life may be affected [73]. Patients with a loss of function mutation in ESR2 have been recently described and associated with complete amenorrhea $[74,75]$ or with $46 \mathrm{XY}$ disorders of sex development [76].

All these findings indicate that the differential level of expression of each ER $\beta$ isoform may play important roles in E2 action and sensitivity, and they might be involved in various follicular deregulations leading to ovarian pathologies, such as polycystic ovary syndrome (PCOS) and granulosa cell tumor (GCT).

\section{Importance of E2 Signaling in PCOS}

\subsection{Down-Regulation of E2 Production}

PCOS is the most common cause of anovulatory infertility affecting $5-10 \%$ of women of reproductive age [77]. In addition to oligomenorrhea/anovulation, women with PCOS are characterized by clinical and/or biochemical hyperandrogenism and polycystic ovaries. PCOS is an endocrine disorder that compromises normal follicular development, with ovaries containing an excess of small antral follicles $(\approx 2-8 \mathrm{~mm}$ in diameter) [78]. In these patients, the recruitment and selection of dominant preovulatory follicles are arrested. FSH levels are below the "threshold" level required during the early follicular phase to stimulate normal follicle maturation, resulting in the impairment of follicular maturation. In addition, an increase in LH pulse frequency [79] participates to premature follicle differentiation [80]. Follicular fluid (FF) within follicles of PCOS women exhibit distinct profiles in proteins and hormones than those of fertile women [81,82], and especially a strong reduction of E2 production despite high levels of androstenedione (the natural substrate of aromatase) [83-86]. The low intra-follicular E2 concentrations [83] may compromise the maturation of developing follicles, thereby favoring the accumulation of a cohort of small antral follicles.

Despite the high prevalence of this disorder, the precise mechanism underlying this phenomenon is poorly understood. Many hypotheses have been formulated, the majority implicating gonadotropin, androgen, and/or growth factor actions. It has been postulated that the elevated circulating LH concentration by itself or the intra-ovarian hyperandrogenism may promote follicle stagnation in the early stages of development by inhibiting the development of a dominant and ovulatory follicle, leading to chronic anovulation 
and infertility. During physiological follicular development, androgens have a biphasic effect on FSH-induced E2 production in primate GC, i.e., augmentation of FSH action by increasing the expression of FSHR [87] in small antral follicles (possibly by up-regulating the expression of ER $\beta$ [88]), which is followed by an inhibition of FSHR expression in the preovulatory follicle [89]. Studies performed on primary cultures of luteinized GC from large antral follicles of non-PCOS women indeed demonstrate the ability of testosterone to down-regulate $C Y P 19 A 1$ expression through the androgen receptor (AR) in a dose-dependent manner [90]. Therefore, excess of androgens may directly down-regulate E2 production in PCOS.

Different studies compared the steroidogenic gene expression profile in GC from the follicles of PCOS to those of non-PCOS women undergoing in vitro fertilization. Results frequently diverge depending on the ovarian stimulation protocol used and/or on the number of included patients. In mural GC, CYP19A1 expression is described to be either unmodified [91,92] or down-regulated $[90,93,94]$ in PCOS when compared to non-PCOS. However, in cumulus GC, CYP19A1 mRNA levels are higher in PCOS when compared to heathy women [95]. These data suggest the existence of differential CYP19A1 expression regulations in GC, depending on their proximity to the oocyte. The down-regulation of both CYP11A1 (encoding cytochrome P450 cholesterol side-chain cleavage enzyme, or P450SCC) and HSD17B1 (encoding 17 $\beta$-hydroxysteroid dehydrogenase enzyme, or 17- $\beta \mathrm{HSD}$ ) and up-regulation of SULT1E1 (sulfotransferase Family 1E Member 1) mRNA expression are observed in mural luteinized GC of PCOS as compared to non-PCOS women [93]. P450SCC catalyzes the conversion of cholesterol to pregnenolone, while 17- $\beta$ HSD and SULT1E1 play a role in estrogen metabolism and biosynthesis [93]. Although we cannot assume that changes in gene expression equate to altered protein expression and function, these data are in favor of a reduction of bioavailable E2 and progesterone in PCOS women.

These comparative studies also measured the expression of gonadotropin receptors and revealed that FSHR expression is unmodified [91] or up-regulated [90,96], while LHCGR expression is either up- or down-regulated $[90,91]$ in PCOS. Despite these contradictory results, we can assume that high levels of LH [79] along with premature LHR activity $[78,97]$ may contribute to PCOS.

In conclusion, in addition to abnormal levels of LH and FSH, antral follicles of PCOS women are characterized by low levels of bioavailable E2 and progesterone, which probably result from abnormal expression and/or activities of different steroidogenic enzymes present in GC.

\subsection{Deregulation of Steroid Hormone Receptors Expression}

Interestingly, the expression pattern analysis of GPER1 (at protein and mRNA levels) in cumulus GC recently has shown its higher expression in PCOS patients when compared to healthy women [98]. GPER1 is proposed to participate in the inhibition of oocyte meiosis described in this pathology [98]. Two studies report an increase in both ER $\alpha$ (ESR1) and ER $\beta$ (ESR2) expression in mural GC of PCOS women [93,99], while a third one described the opposite [100]; these discrepancies can stem from the difference in the ovarian stimulation protocol used. These investigations did not quantify the expression levels of each ER $\beta$ isoform present in luteinized GC [30]. Therefore, further data on the respective expression level of ER $\beta$ isoforms in GC from PCOS and non-PCOS women will be helpful to better understand E2 signaling in PCOS. In addition, it is postulated that epigenetic alterations in the CYP19A1 gene would modify ER $\beta$ binding to the DNA and prevent aromatase expression in PCOS [95]. Therefore, an alteration of ER $\beta$ isoforms expression and/or DNA accessibility may participate in this pathology. Meanwhile, deregulations of the expression of other sex steroid hormone receptors are similarly described in PCOS, with either an unmodified [91] or an up-regulation [96] of AR expression and a down-regulation of progesterone receptor A expression [100] in mural GC from PCOS follicles.

Taken together, these different studies demonstrate the existence of various alterations in GC hormonal receptivity within PCOS follicles that could markedly modify GC functions. 


\subsection{Deficiency in Aromatase Activity and Role of Follicular Fluid Components}

Studies examining the relationship between aromatase activity and E2 production in PCOS follicles report interesting findings. Indeed, primary cultures of GC from PCOS follicles are responsive to FSH in vitro since they produce markedly increased levels of E2 $[78,86]$. These cells also show premature LH responsiveness (early acquisition of LHR) leading to progesterone synthesis [97]. These data suggest that endogenous inhibitors may be responsible for the lack of in vivo aromatase function. The composition of FF may have an impact on aromatase activity; FF from dominant follicles (as opposed to non-dominant follicles) has the ability to decrease aromatase activity [101]. FF compounds that negatively affect aromatase activity were investigated and revealed to be principally steroid hormones. Indeed, FF from small (5-8 mm diameter) PCOS or healthy follicles, pretreated with charcoal to eliminate steroids, increase GC aromatase conversion activity, at least partially through increasing substrate affinity $\left(\mathrm{K}_{\mathrm{d}}\right.$ of $\left[{ }^{11} \mathrm{C}\right]$ vorozole lower in charcoal-pretreated FF compared to untreated FF). Although charcoal treatment leads to the depletion of additional substances, these findings led to the proposal that steroids could act as endogenous inhibitors of aromatase activity [102]. Among steroids, Agarwal et al. reported that the high concentration of $5 \alpha$-reduced androgens in FF of PCOS follicles can decrease aromatase activity in primary cultures of GC [86].

In addition to steroids, other factors, which are highly present in the FF of PCOS (when compared to normal matched for FF-volume), can also down-regulate aromatase activity, such as anti-Müllerian hormone (AMH) [103], epidermal growth factor EGF [104], or/and interleukin-6 (IL-6) [83,105]. During follicle development, AMH is produced exclusively by GC, starting at the primary follicle stage, progressively surging up to a peak in small antral follicle and then gradually disappearing in large follicles, except in cumulus GC. AMH inhibits FSH-induced E2 production by GC through inhibition of the catalytic activity of adenylate cyclase [87], therefore preventing the growth and selection of follicles in PCOS [106]. This direct relationship between AMH and E2 can be determined since the serum E2 level starts to rise only once the serum AMH level passes under some threshold [107]. Meanwhile, EGF and IL-6 are also potent inhibitors of E2 and progesterone production in human GC $[108,109]$ and could synergize with AMH to decrease aromatase expression/activity through different molecular mechanisms. Indeed, the rapid effect (within $2 \mathrm{~h}$ ) of FF to decrease aromatase activity in GC could involve non-genomic mechanisms through aromatase phosphorylation [102]. Actually, a conserved phosphorylation site (serine 118 in human) has a significant effect on decreasing aromatase activity and might be an important process in regulating aromatase activity in GC [110].

Hence, all these data indicate that despite high intra-follicular concentrations of androstenedione and bioactive FSH in PCOS follicles, $5 \alpha$-reduced androgens together with other factors such as AMH, EGF, and/or IL-6, may decrease aromatase activity within GC to down-regulate $\mathrm{E} 2$ production in vivo.

\subsection{Potential Effect of Low E2 Concentrations on FF Composition}

In addition to displaying reduced concentration of E2, the FF of PCOS woman follicles are also characterized by a reduction of inhibin $\mathrm{A}$ and $\mathrm{B}$ concentrations when compared to the FF of sized-matched follicles of healthy women [111]. Inhibin A and inhibin B secretions are regulated differently in vitro, with FSH stimulating inhibin A, but not inhibin B, secretion from human GC primary cultures [112]. Therefore, deficiency in FSH stimulation is probably not the only etiology of both inhibin A/B reduction in PCOS. On the other hand, E2 is an interesting regulator candidate, since it stimulates inhibin B expression [113]. One could speculate that the reduced production of E2 measured in PCOS follicles may contribute to the lower levels of inhibin B measured in the FF. Contrary to inhibin, IL-6 increases significantly in the FF of PCOS follicles [83,105], and this cytokine is known to decrease E2 production by reducing Cyp19A1 expression in rat GC [114]. Since E2 is able to inhibit NFK-B-mediated up-expression of IL-6 [115], its lower production in PCOS could reinforce the higher production of IL-6 observed in FF of PCOS follicles. In addition, E2 
is also able to down-regulate TGF $\beta$ secretion [116] that usually acts as a potent inhibitor of thecal androgen production in rat [117]. Considering that these regulations might be conserved in human, one could postulate that the decrease in E2 production measured in PCOS could stimulate androgens production in thecal cells. Altogether, bidirectional relationships between E2 concentration and that of growth factors (TGF $\beta$ [116], EGF [118]), AMH [119], or IL-6 [115] present in PCOS FF highlight the potential role of E2 signaling in PCOS and complicate the understanding of its etiology (Figure 2).
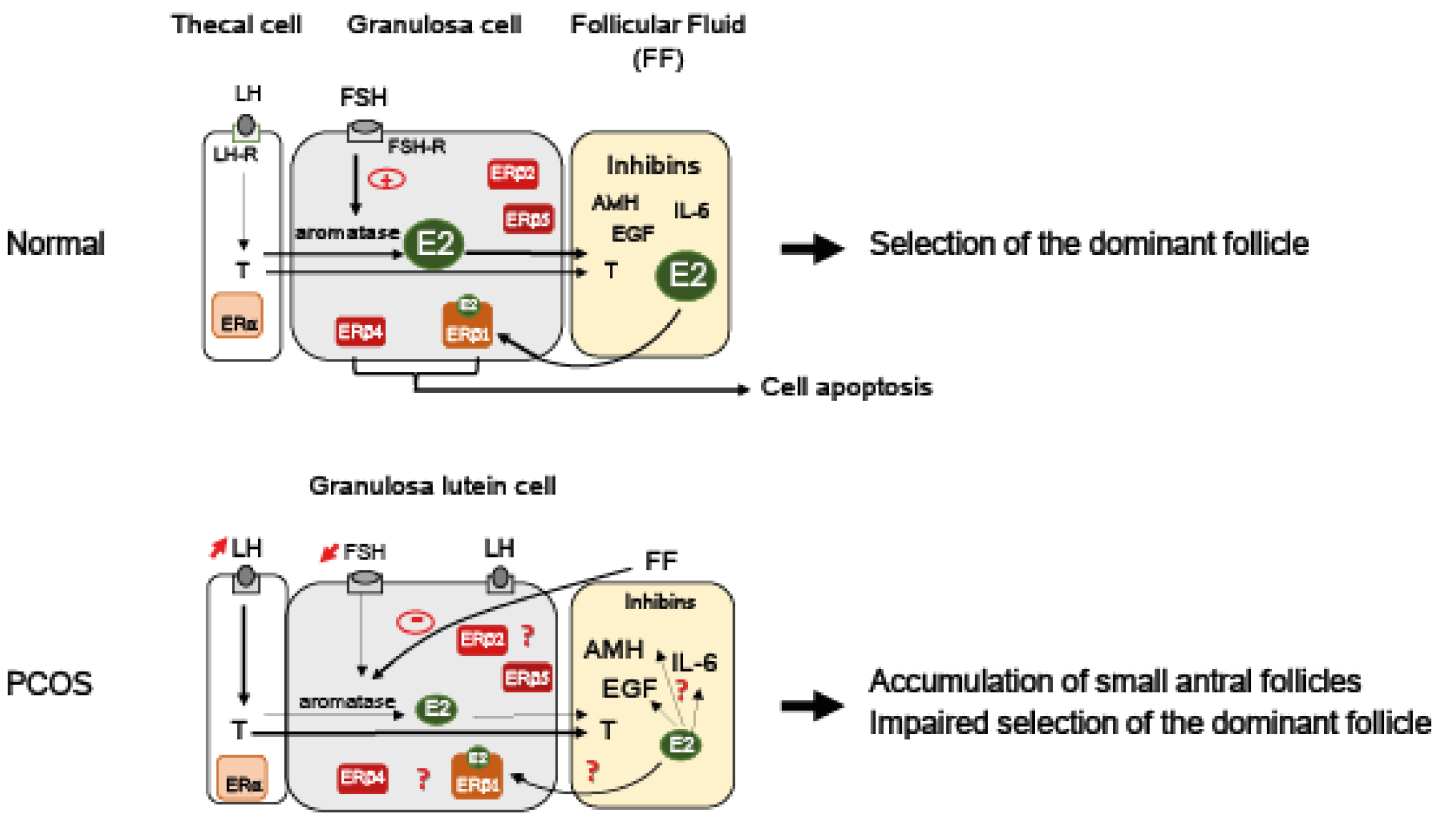

Figure 2. Working model for the role of E2 signaling in PCOS follicles. In granulosa cells (GC) of small antral follicles, FSH stimulates the expression of the aromatase that converts thecal-derived androgens (i.e., testosterone (T) produced upon LH stimulation) to estrogens (E2). E2 contained in the follicular fluid (FF) synergizes with FSH to promote follicular growth and further participates in the selection of the dominant preovulatory follicle [1,3]. The FF of normal antral follicle contains a large set of proteins and hormones such as high levels of inhibins and E2 together with low concentrations of anti-Müllerian hormone (AMH), interleukin-6 (IL-6), epidermal growth factor (EGF), or T. Contrary to thecal cells that principally express ER $\alpha$, GC mainly express ER $\beta$ isoforms [29,30]. Among them, only ER $\beta 1$ binds to E2 [20]. ER $\beta 1$ as well as ER $\beta 4$ possess pro-apoptotic activities that may influence follicles' fate [30]. In PCOS follicles, abnormal high levels of LH stimulate the T production of thecal cells. In addition to deficit in $\mathrm{FSH}$, endogenous inhibitors (principally steroids) present in the FF [101,102] down-regulate aromatase activity, resulting in lower E2 production. Lower levels of E2 might participate in a higher production of AMH, IL-6, and/or EGF present in PCOS FF $[83,105,115,118,119]$. Low intra-follicular E2 concentrations may compromise the maturation of developing follicles and favor the accumulation of small antral follicles. The GC of PCOS follicles prematurely express LH receptors (LH-R) [80], which participate in the early maturation of these follicles. The expression levels of each ER $\beta$ isoform are still unknown. Specific ER $\beta$ isoforms expression might influence follicular fate and contribute to the high number of follicles that characterizes this pathology [78]. LH: Luteinizing hormone; FSH: Follicle-stimulating hormone; LH-R: LH receptor.

\subsection{Potential Role of E2 Reduction on GC Survival}

GC survival is described to be altered in PCOS [120,121]. Analysis of GC from small follicles (4-8 mm diameter) of PCOS and non-PCOS patients reveal a decreased expression of the apoptotic effector caspase-3 together with an increased expression of the anti-apoptotic survival factor cIAP-2 (cellular inhibitor of apoptosis protein 2) in PCOS [120]. On the other hand, GC from larger (16-18 mm diameter) PCOS follicles show a higher apoptosis activity (activation of Forkhead box O3) than those of healthy ones [121]. Thus, these data suggest 
that depending on the size of the follicle, GC are differently sensitive to apoptotic signals, which possibly lead to differential follicle fate in PCOS.

Among the factors that could regulate GC fate in PCOS, one could cite AMH. Indeed, a protective effect of $\mathrm{AMH}$ on follicle atresia has been recently described with $\mathrm{AMH}$-target genes being differently regulated in GC of PCOS compared to non-PCOS women [122]. E2 may also contribute to GC fate in PCOS, as depicted in rhesus monkeys, high concentrations of E2 inducing atresia of antral follicles [3]. In addition, E2 specifically regulates the expression of ER $\beta$ isoforms, of which two can trigger apoptotic events in GC [30]. E2, by regulating specific ER $\beta$ isoform expression in GC of PCOS, might participate in their follicular fate.

Further studies are still needed to better understand whether PCOS follicles are indeed protected from atresia. If it is confirmed, these processes would then contribute to the higher number of follicles that characterizes this pathology.

\section{Roles of Estrogen in GCT}

\subsection{Most GCT Are E2-Secreting Tumors}

GCT are the most common type of potentially malignant ovarian sex cord-stromal tumor that represent $5 \%$ of all ovarian malignancies [123]. These tumors are proposed to arise from the default of apoptosis and rapid proliferation of GC from growing follicles destined to atresia [124,125]. There are two distinct subtypes of GCT with different clinical and histopathological parameters: the juvenile (diagnosed around puberty) and the adult (frequently peri- and post-menopausal women) GCT. These tumors are characterized by their slow growth and late recurrence. They are usually treated by surgery alone and have a good prognosis (a 5-year survival rate from 75 to $90 \%$ ). However, recurrence is associated with poor prognosis, since more than $80 \%$ of patients will die. GCT are functional tumors that may produce excessive levels of E2 either because of the up-regulation of CYP19A1 expression [126,127] or the high number of tumor cells producing E2 [125]. This hyperestrogenism is responsible for GCT-specific clinical signs such as abnormal vaginal bleeding and precocious puberty [123]. Although E2 is the hormone responsible for the observed clinical manifestations and can be used as a reliable GCT marker, its fluctuating levels in patients cannot predict the tumor activity [128]. GCT show FSH-like growth stimulation despite low FSH levels and the absence of activating mutations in FSHR gene [124], with a high production of E2 and inhibins. Excess of inhibins production exerts negative feedback on FSH secretion that becomes unusually low. Serum inhibins as well as AMH levels are frequently abnormally high in patients with GCT [128]; combining AMH levels with inhibins estimation is shown to improve the detection of recurrent disease [129].

The exact etiology of GCT has not been elucidated, and the molecular switches that trigger the progression of the disease in advanced stages remain unresolved. Molecular genetic studies propose that these tumors have a somatic missense point mutation (c.402C > G) in the FOXL2 (Forkhead box L2) gene, which is observed in $97 \%$ of adult GCT and in 5\% of juvenile GCT [123], which represents a key element that distinguishes juvenile from adult GCT. FOXL2 is an essential transcription factor controlling the proliferation, apoptosis, and steroidogenesis of GC [130]. FOXL2 mutation (C134W) results in CYP19A1 up-regulation, probably through ER $\beta$ [131], leading to high E2 production [132]. FOXL2 mutation impacts on many signaling pathways involved in GC proliferation and apoptosis, i.e., inducing the suppression of follistatin expression or blockage of caspase-8/Bak (Bcl-2 family member)-related apoptotic pathways [133]. Recently, our study on a GCT mouse model suggests that the disruption of $\mathrm{p} 53 / \mathrm{Rb}$ (retinoblastoma protein) signaling could drive tumor initiation and growth in antral follicles [125].

\subsection{Role of E2 Signaling in GCT}

The direct contribution of E2 in GCT oncogenesis is still largely unknown. Since GCT account for about $5 \%$ of ovarian malignancies with an incidence of 0.52 to 1.6 per 100,000 women per year [128], studies about GPER1 and steroid hormone receptor dis- 
tributions in GCT are quite limited. Contradicting patterns of GPER1 expression show that $14 \%$ to $90 \%$ of GCT express GPER1 [134-136] with either an up-regulation [136] or an unchanged expression between primary and recurrent tumors $[134,135]$. On the other hand, ER $\beta$ is reported to be preferentially expressed in GCT $[31,136,137]$ along with a high expression of AR (59\% of positive cells are AR positive [138]) and PR (98-100\% of positive cells are PR positive), while ER $\alpha$ is present at moderate to high levels (20-66\% of GCT are ER $\alpha$ positive) in these tumors [31,136,139-142]. These different observations may partly be explained by the small patient samples, the use of arbitrary cutoff points for interpreting positive immunoreactivity, and the lack of valuable antibodies [143]. Paired analysis of a small number of primary and recurrent samples from the same patient demonstrate a significantly stronger ER $\beta$ immunoreactivity in the recurrent GCT compared to the primary tumor [136]. However, the absence of ER $\beta$ in primary GCT is characterized by a worse prognosis [137].

All these reports assessed total ER $\beta$ or ER $\beta 1[136,137,139]$, except for two studies that show a strong expression of ER $\beta 2$ and ER $\beta 5$ in GCT [31,33]. ER $\beta 1, E R \beta 2$, and ER $\beta 5$ are highly expressed in the nucleus of all studied GCT cells [33]. ER $\beta 2$ is also depicted to display a punctate distribution in the cytosol that reflects a mitochondrial localization. Interestingly, ER $\beta 2$ is able to interact with proteins of the Bcl-2 family [33], which are highly detected in GCT [144] and play an important role in preventing cell apoptosis. ER $\alpha$ and ER $\beta$ are indeed described to be present in the mitochondria of various cell types and tissues [145], being able to regulate mitochondrial activities [146]. Our search in Mitoproteome, a human mitochondrial protein database (www.mitoproteome.org accessed on 23 December 2021), yields no results for ER $\alpha$ but reveals the presence of all isoforms of ER $\beta$ (unpublished observations). These data suggest a distinct function between cytoplasmic and nuclear ER $\beta$ through genomic, non-genomic, and mitochondrial mechanisms.

Although various estrogen receptors are expressed in GCT, the role of E2 in this form of tumor has been purely speculative for a long time. Based on the idea that E2 promotes tumor growth in various cancers [41], anti-estrogen therapies with aromatase inhibitors are currently used in patients with recurrence [147]. Studies on human metastatic and primary granulosa tumor cells (KGN, COV434) did not support a growth-stimulating effect of E2 $[33,135,136,148]$. However, in these cells, ER-mediated transactivation is not functional because of the constitutive activation of NFK-B $[135,148]$. In this context wherein ER signaling is inactive, we observed that E2 decreases KGN cell migration through GPER1-mediated ERK1/2 inactivation, therefore possibly preventing GCT metastasis spreading [135]. Two studies, including ours in a mouse GCT cell line wherein ER signaling is active, support the idea that E2 favors the growth of GCT by promoting cell survival [136,142]. This E2-mediated effect may be triggered by $\mathrm{ER} \alpha$, acting either alone or in combination with $\mathrm{ER} \beta$ [142]. The ER $\alpha$-dependency for the pro-survival action of E2 in GCT may explain the relatively limited clinical benefits of aromatase inhibitors, since not all GCT express $\mathrm{ER} \alpha[31,136,139-142]$. In addition, this effect of ER $\beta$ in GCT would be different from that described in other cancers, wherein this receptor is generally described as an anti-proliferative factor that is down-regulated in breast (BC), prostate (PC), and epithelial ovarian cancers (OC) $[67,69,149]$. ER $\beta$ that commonly corresponds to ER $\beta 1$ is generally presented as a tumor suppressor that blocks cell proliferation and induces cell apoptosis [150]. However, the role of $\mathrm{ER} \beta$ as a tumor suppressor is still controversial and may be tissue-dependent. $\mathrm{ER} \beta$ may have a bi-faceted role as reported in BC cancers, in which ER $\beta$ activation either prevents or promotes cell growth, depending on the presence or the absence of ER $\alpha$, respectively [69]; when present together with $\mathrm{ER} \alpha, \mathrm{ER} \beta$ generally has a restraining effect on $\mathrm{ER} \alpha$ activities [69], contrasting with its action in GCT [142]. Since ER homo- and heterodimers regulate different sets of downstream target genes, the ER expression ratios (ER $\alpha$ : ER $\beta$ isoforms) may then be an important determinant in ER-mediated signaling pathways. On the other hand, ER $\beta$ effects might be even more complex than they appear when considering each ER $\beta$ isoform. Indeed, higher mRNA levels of ER $\beta 2$ than the ER $\beta 1$ isoform are correlated with better survival in late-onset ER $\alpha$-positive BC [151], whereas high mRNA 
levels of ER $\beta 1$ and ER $\beta 5$ may contribute to poor survival of patients with ER $\alpha$-negative BC tissue [152]. GCT express different ER $\beta$ isoforms [33], which could greatly influence tumor progression. One could speculate that the ligand-insensitive ER $\beta$ isoforms could participate in cell growth independently of E2. Further investigations are needed to determine whether $\mathrm{ER} \beta$ isoforms could play a role in GCT growth. An additional level of complexity of these regulations arises from ER $\beta$ subcellular localization that could also account for different effects. Two independent and contradictory studies on OC report that the presence of $\mathrm{ER} \beta$ in the cytosol is an unfavorable prognostic factor for disease-free survival $[153,154]$, while another depicts that nuclear ER $\beta$ shortens progression-free survival [155]. Focusing the analysis on the subcellular localization of ER $\beta$ isoforms can also give various results depending on tumor types. Indeed, a large PC sample analysis shows that the majority $(>80 \%)$ of the specimens are positive for cytoplasmic ER $\beta 1$ and nuclear ER $\beta 2$ (nER $\beta 2)$, and $36 \%$ are positive for cytoplasmic ER $\beta 5$ (cER 35 ) [156]. Patients positive for both ER $\beta 2$ and $\mathrm{ER} \beta 5$ (nER $\beta 2+$ and cER $\beta 5+$ ) exhibit a worst clinical outcome. The ectopic expression of $E R \beta 2$ and $E R \beta 5$ in prostatic cell lines further uncovers that these two isoforms are strongly associated with PC metastasis [68,156] and chemotherapy resistance [157]. By contrast, in $\mathrm{BC}$ and OC, cytosolic ER $\beta 2$ localization correlates with shorter overall survival at 15 years and with chemoresistance $[32,158,159]$. Discrepancy in correlations between ER $\beta$ isoforms expression/localization and function between BC/OC and PC suggests a fundamental difference in the role played by E2 signaling in these pathogeneses. All these studies reveal that there are ER subtype-specific expression changes in cancer that varies depending on tumor type and disease stage. These findings suggest that according to the different pathological circumstances, various binding partners, such as hormone receptors [160] or other proteins [161], could modify ER $\beta$ functions and then lead to different outcomes.

\subsection{ER $\beta$ as A New Therapeutic Target?}

Hormone therapy has limited success in the treatment of recurrent GCT [147], which can be attributed to the relative expression levels of $E R \alpha$ and $E R \beta$ isoforms. The ratio of ER $\alpha$ to $\mathrm{ER} \beta$ correlates with progressive steps along tumorigenesis. However, to assess whether hormone receptivity is still present or lost during disease progression or chemotherapy, it would be of high interest to undertake a larger analysis of the expression profiles of hormone receptors between primary diagnosed and relapsed cases. These investigations would help to improve patient therapies. PR and AR are frequently highly expressed in GCT and can influence the action of ER [160], and they could explain the observed variation in the responsiveness to anti-estrogen therapies [147]. Further studies aiming at examining whether inhibition of both ER and AR could be efficient in the treatment of GCT need to be evaluated [136]. Strategic coupling of agents targeting several pathways should be considered for a greater efficacy in therapy.

Botanical estrogens are widely consumed in the diet or as dietary supplements by women and preferentially bind to ER $\beta$ (lost at high concentrations, $>1 \mu \mathrm{M}$ ) [162]. They still bind ER with a 1000-fold lower affinity than E2 [162]. Interestingly, Liu et al. report a significant growth inhibition of natural ER $\beta$ agonists (liquiritigenin, Liq, and S-equal) through pro-apoptotic actions on OC [163]. When compared to E2-modulating gene expression in MCF-7 breast cancer cells, ER $\beta$ botanical agonists are depicted to be less stimulatory on gene expression promoting proliferation and motility, while they are more effective in up-regulating apoptotic genes [164]. These data open a promising perspective and need to be investigated on GCT growth.

The high expression of ER $\beta$ observed in GCT suggests that E2 could also act on a tumor environment [123]. The growth of tumors is known to be dependent on neovascularization to provide the tumor with all required nutrients [165]. Therefore, it would be interesting to explore the role of E2 on angiogenesis. Angiogenesis is an essential process in normal tissue growth, and it involves multiple factors such as vascular endothelial growth factor (VEGF), platelet-derived growth factor $\beta$ (PDGF $\beta)$, or the basic fibroblast growth factor (bFGF). Interestingly, the introduction of ER $\beta 1$ into malignant BC injected orthotopically in 
immunodeficient mice inhibits their growth and prevents tumor expansion by inhibiting angiogenesis through the down-regulation of both PDGF $\beta$ and VEGF expression [166].

In conclusion, all these studies point out the importance of determining the exact hormone receptor status (ER $\alpha, E R \beta$ isoforms, GPER1, AR, PR) in GCT that could vary between patients and tumor stages (Figure 3). Improvement in getting this information will ensure the use of relevant hormonal therapies yielding higher success in GCT treatments.

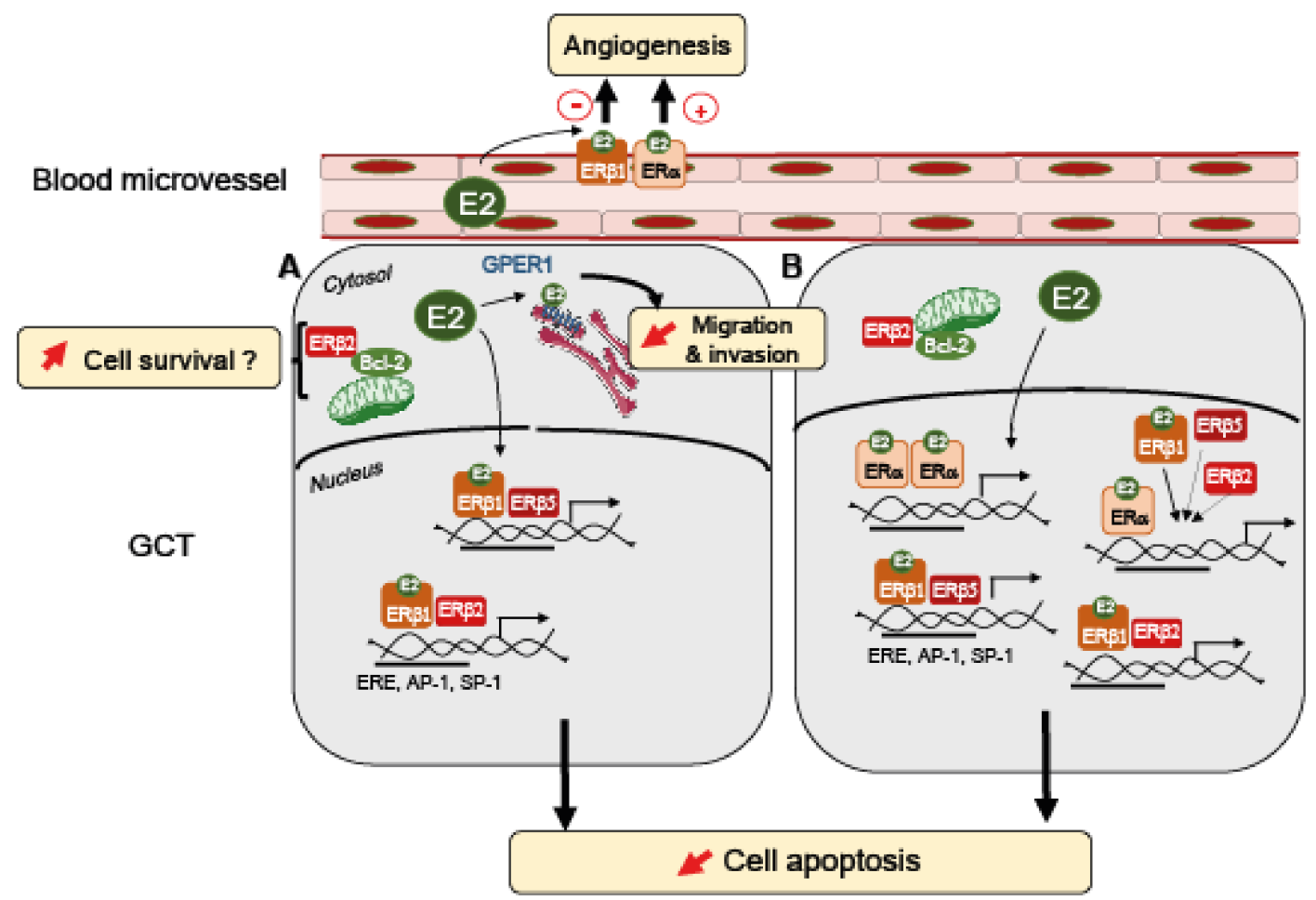

Figure 3. Working hypothesis for a role of E2 signaling in GCT. ER $\beta$ is expressed in all GCT [31,136,137]. There is a heterogeneity of ER subtypes expression among GCT [31,136,137,139-142]. In GCT, all ER $\beta$ isoforms are localized in the nucleus [31,33], except for ER $\beta 2$, which is also present in the cytosol, possibly interacting with mitochondrial Bcl-2 [33] to promote GCT survival. GCT produce E2 that could bind to GPER1 and promote the inhibition of GCT migration and invasion, in the absence of ER $\alpha$ [135] (A). In addition, E2 could bind to ER $\beta 1$, which would either homodimerize or heterodimerize with ER $\beta 5$ or ER $\beta 2$ [20], in the absence of $\mathrm{ER} \alpha$, to regulate pro-survival or pro-apoptotic gene expression, through DNA interactions with ERE, AP-1, or SP-1 sites [56]. ER $\beta 1, E R \beta 2$, and ER $\beta 5$ might also trigger non-genomic pathways that still need to be identified in GCT. (B) In the presence of ER $\alpha$, E2 binding would induce its homo- or heterodimerization with other ER subtypes that would finally regulate the expression of other sets of pro-survival genes. ER $\beta$ isoforms inhibit the transcriptional activity of ER $\alpha$ [22]. In addition, E2 could also bind to $\mathrm{ER} \beta 1$ or $\mathrm{ER} \alpha$, which are expressed in endothelial cells, to respectively reduce or stimulate angiogenesis $[166,167]$. The presence of specific ER subtypes probably orientates the fate of GCT.

\section{Concluding Remarks}

In this review, we highlight the potential roles of E2 in two human ovarian pathologies. We provide evidence that the ratio of ER expression, especially that of ER $\beta$ isoforms, is crucial for GC proliferation and apoptosis and may be essential in the development of normal or tumor-derived follicles. The existence of a highly complex E2 signaling with multiple ER $\beta$ isoforms suggests that yet unidentified deregulation could contribute to subtle endocrine-related ovarian disorders causing idiopathic infertility.

One of the important future challenges is to detect each ER $\beta$ isoform protein in single-cell analyses, but it requires reliable isoform-specific antibodies that are not yet 
available. Therefore, alternative antibody-free techniques must be developed to scrutinize ER heterogeneity in situ within different follicles or within GCT. In addition, assuming that $E R \beta$ isoforms (especially $E R \beta 2, E R \beta 4$, and $E R \beta 5$ ) possess large genomic activities independently of the presence of E2, new programs of in silico designed drugs need to be carried out, focusing on other conformational situations than the optimal E2-bound $\mathrm{ER} \beta$. Hence, the study of the potency of natural agonists or the development of new drugs directly regulating specific ER $\beta$ isoform activities needs to be considered. It would lead to the emergence of useful tools to restore GC functions that are deregulated in ovarian-related pathologies as well as in other diseases.

Author Contributions: S.C. designed, wrote, and edited the manuscript. J.C.-T. edited the manuscript. C.J.G. wrote and edited the manuscript. All authors have read and agreed to the published version of the manuscript.

Funding: This work was supported by "Institut National de la Santé \& de la Recherche Médicale" (Inserm), "Centre National de la Recherche Scientifique" (CNRS) and Université de Paris.

Data Availability Statement: Not applicable.

Conflicts of Interest: The authors declare no conflict of interest.

\section{References}

1. McNatty, K.P.; Moore Smith, D.; Osathanondh, R.; Ryan, K.J. The human antral follicle: Functional correlates of growth and atresia. Ann. Biol. Anim. Bioch. Biophys. 1979, 19, 1547-1558. [CrossRef]

2. Amsterdam, A.; Gold, R.S.; Hosokawa, K.; Yoshida, Y.; Sasson, R.; Jung, Y.; Kotsuji, F. Crosstalk Among Multiple Signaling Pathways Controlling Ovarian Cell Death. Trends Endocrinol. Metab. 1999, 10, 255-262. [CrossRef]

3. Hutz, R.J.; Dierschke, D.J.; Wolf, R.C. Estradiol-induced follicular atresia in rhesus monkeys is not prevented by exogenous gonadotropins. Am. J. Primatol. 1991, 23, 247-255. [CrossRef]

4. Taylor, S.E.; Martin-Hirsch, P.L.; Martin, F.L. Oestrogen receptor splice variants in the pathogenesis of disease. Cancer Lett. 2010, 288, 133-148. [CrossRef] [PubMed]

5. Prossnitz, E.R.; Hathaway, H.J. What have we learned about GPER function in physiology and disease from knockout mice? J. Steroid Biochem. Mol. Biol. 2015, 153, 114-126. [CrossRef] [PubMed]

6. Scobie, G.A.; Macpherson, S.; Millar, M.R.; Groome, N.P.; Romana, P.G.; Saunders, P.T. Human oestrogen receptors: Differential expression of ER alpha and beta and the identification of ER beta variants. Steroids 2002, 67, 985-992. [CrossRef]

7. Saunders, P.T.; Millar, M.R.; Williams, K.; Macpherson, S.; Harkiss, D.; Anderson, R.A.; Orr, B.; Groome, N.P.; Scobie, G.; Fraser, H.M. Differential expression of estrogen receptor-alpha and -beta and androgen receptor in the ovaries of marmosets and humans. Biol. Reprod. 2000, 63, 1098-1105. [CrossRef] [PubMed]

8. Herynk, M.H.; Fuqua, S.A. Estrogen receptor mutations in human disease. Endocr. Rev. 2004, 25, 869-898. [CrossRef]

9. Wang, Z.Y.; Yin, L. Estrogen receptor alpha-36 (ER-alpha36): A new player in human breast cancer. Mol. Cell Endocrinol. 2015, 418, 193-206. [CrossRef]

10. Flouriot, G.; Brand, H.; Denger, S.; Metivier, R.; Kos, M.; Reid, G.; Sonntag-Buck, V.; Gannon, F. Identification of a new isoform of the human estrogen receptor-alpha (hER-alpha) that is encoded by distinct transcripts and that is able to repress hER-alpha activation function 1. EMBO J. 2000, 19, 4688-4700. [CrossRef]

11. Barraille, P.; Chinestra, P.; Bayard, F.; Faye, J.C. Alternative initiation of translation accounts for a $67 / 45 \mathrm{kDa}$ dimorphism of the human estrogen receptor ERalpha. Biochem. Biophys. Res. Commun. 1999, 257, 84-88. [CrossRef] [PubMed]

12. Chantalat, E.; Boudou, F.; Laurell, H.; Palierne, G.; Houtman, R.; Melchers, D.; Rochaix, P.; Filleron, T.; Stella, A.; Burlet-Schiltz, O.; et al. The AF-1-deficient estrogen receptor ERalpha46 isoform is frequently expressed in human breast tumors. Breast Cancer Res. 2016, 18, 123. [CrossRef]

13. Maaroufi, Y.; Lacroix, M.; Lespagnard, L.; Journe, F.; Larsimont, D.; Leclercq, G. Estrogen receptor of primary breast cancers: Evidence for intracellular proteolysis. Breast Cancer Res. 2000, 2, 444-454. [CrossRef]

14. Penot, G.; Le Peron, C.; Merot, Y.; Grimaud-Fanouillere, E.; Ferriere, F.; Boujrad, N.; Kah, O.; Saligaut, C.; Ducouret, B.; Metivier, R.; et al. The human estrogen receptor-alpha isoform hERalpha46 antagonizes the proliferative influence of hERalpha66 in MCF7 breast cancer cells. Endocrinology 2005, 146, 5474-5484. [CrossRef] [PubMed]

15. Leygue, E.; Murphy, L.C. A bi-faceted role of estrogen receptor beta in breast cancer. Endocr. Relat Cancer 2013, 20, R127-R139. [CrossRef]

16. Moore, J.T.; McKee, D.D.; Slentz-Kesler, K.; Moore, L.B.; Jones, S.A.; Horne, E.L.; Su, J.L.; Kliewer, S.A.; Lehmann, J.M.; Willson, T.M. Cloning and characterization of human estrogen receptor beta isoforms. Biochem. Biophys. Res. Commun. 1998, 247, 75-78. [CrossRef] [PubMed]

17. Shoda, T.; Hirata, S.; Kato, J.; Hoshi, K. Cloning of the novel isoform of the estrogen receptor beta cDNA (ERbeta isoform M cDNA) from the human testicular cDNA library. J. Steroid Biochem. Mol. Biol. 2002, 82, 201-208. [CrossRef] 
18. Donoghue, L.J.; Neufeld, T.I.; Li, Y.; Arao, Y.; Coons, L.A.; Korach, K.S. Differential Activation of a Mouse Estrogen Receptor beta Isoform (mERbeta2) with Endocrine-Disrupting Chemicals (EDCs). Environ. Health Perspect 2017, 125, 634-642. [CrossRef]

19. Sierens, J.E.; Scobie, G.A.; Wilson, J.; Saunders, P.T. Cloning of oestrogen receptor beta from Old and New World primates: Identification of splice variants and functional analysis. J. Mol. Endocrinol. 2004, 32, 703-718. [CrossRef]

20. Leung, Y.K.; Mak, P.; Hassan, S.; Ho, S.M. Estrogen receptor (ER)-beta isoforms: A key to understanding ER-beta signaling. Proc. Natl. Acad. Sci. USA 2006, 103, 13162-13167. [CrossRef]

21. Poola, I.; Abraham, J.; Baldwin, K.; Saunders, A.; Bhatnagar, R. Estrogen receptors beta4 and beta5 are full length functionally distinct ERbeta isoforms: Cloning from human ovary and functional characterization. Endocrine 2005, 27, 227-238. [CrossRef]

22. Peng, B.; Lu, B.; Leygue, E.; Murphy, L.C. Putative functional characteristics of human estrogen receptor-beta isoforms. J. Mol. Endocrinol. 2003, 30, 13-29. [CrossRef] [PubMed]

23. Hall, J.M.; McDonnell, D.P. The estrogen receptor beta-isoform (ERbeta) of the human estrogen receptor modulates ERalpha transcriptional activity and is a key regulator of the cellular response to estrogens and antiestrogens. Endocrinology 1999, 140, 5566-5578. [CrossRef]

24. Cowley, S.M.; Parker, M.G. A comparison of transcriptional activation by ER alpha and ER beta. J. Steroid Biochem. Mol. Biol. 1999, 69, 165-175. [CrossRef]

25. Ogawa, S.; Inoue, S.; Watanabe, T.; Orimo, A.; Hosoi, T.; Ouchi, Y.; Muramatsu, M. Molecular cloning and characterization of human estrogen receptor betacx: A potential inhibitor ofestrogen action in human. Nucleic Acids Res. 1998, 26, 3505-3512. [CrossRef]

26. Zhao, C.; Matthews, J.; Tujague, M.; Wan, J.; Strom, A.; Toresson, G.; Lam, E.W.; Cheng, G.; Gustafsson, J.A.; Dahlman-Wright, K. Estrogen receptor beta2 negatively regulates the transactivation of estrogen receptor alpha in human breast cancer cells. Cancer Res. 2007, 67, 3955-3962. [CrossRef]

27. Mott, N.N.; Pak, T.R. Characterisation of human oestrogen receptor beta (ERbeta) splice variants in neuronal cells. J. Neuroendocrinol. 2012, 24, 1311-1321. [CrossRef]

28. Mueller, S.O.; Katzenellenbogen, J.A.; Korach, K.S. Endogenous estrogen receptor beta is transcriptionally active in primary ovarian cells from estrogen receptor knockout mice. Steroids 2004, 69, 681-686. [CrossRef] [PubMed]

29. Poola, I. Molecular assays to profile 10 estrogen receptor beta isoform mRNA copy numbers in ovary, breast, uterus, and bone tissues. Endocrine 2003, 22, 101-112. [CrossRef]

30. Pierre, A.; Mayeur, A.; Marie, C.; Cluzet, V.; Chauvin, J.; Frydman, N.; Grynberg, M.; Cohen-Tannoudji, J.; Guigon, C.J.; Chauvin, S Estradiol Regulates mRNA Levels of Estrogen Receptor Beta 4 and Beta 5 Isoforms and Modulates Human Granulosa Cell Apoptosis. Int. J. Mol. Sci. 2021, 22, 5046. [CrossRef]

31. Chu, S.; Mamers, P.; Burger, H.G.; Fuller, P.J. Estrogen receptor isoform gene expression in ovarian stromal and epithelial tumors. J. Clin. Endocrinol. Metab. 2000, 85, 1200-1205. [PubMed]

32. Ciucci, A.; Zannoni, G.F.; Travaglia, D.; Petrillo, M.; Scambia, G.; Gallo, D. Prognostic significance of the estrogen receptor beta (ERbeta) isoforms ERbeta1, ERbeta2, and ERbeta5 in advanced serous ovarian cancer. Gynecol. Oncol. 2014, 132, 351-359. [CrossRef] [PubMed]

33. Ciucci, A.; Ferrandina, G.; Mascilini, F.; Filippetti, F.; Scambia, G.; Zannoni, G.F.; Gallo, D. Estrogen receptor beta: Potential target for therapy in adult granulosa cell tumors? Gynecol. Oncol. 2018, 150, 158-165. [CrossRef] [PubMed]

34. van den Driesche, S.; Smith, V.M.; Myers, M.; Duncan, W.C. Expression and regulation of oestrogen receptors in the human corpus luteum. Reproduction 2008, 135, 509-517. [CrossRef]

35. Hirata, S.; Shoda, T.; Kato, J.; Hoshi, K. The multiple untranslated first exons system of the human estrogen receptor beta (ER $\beta$ ) gene. J. Steroid Biochem. Mol. Biol. 2001, 78, 33-40. [CrossRef]

36. Smith, L.; Coleman, L.J.; Cummings, M.; Satheesha, S.; Shaw, S.O.; Speirs, V.; Hughes, T.A. Expression of oestrogen receptor beta isoforms is regulated by transcriptional and post-transcriptional mechanisms. Biochem. J. 2010, 429, 283-290. [CrossRef]

37. Smith, L.; Brannan, R.A.; Hanby, A.M.; Shaaban, A.M.; Verghese, E.T.; Peter, M.B.; Pollock, S.; Satheesha, S.; Szynkiewicz, M.; Speirs, V.; et al. Differential regulation of oestrogen receptor beta isoforms by 5 ' untranslated regions in cancer. J. Cell Mol. Med. 2010, 14, 2172-2184. [CrossRef]

38. Al-Nakhle, H.; Burns, P.A.; Cummings, M.; Hanby, A.M.; Hughes, T.A.; Satheesha, S.; Shaaban, A.M.; Smith, L.; Speirs, V. Estrogen receptor $\beta 1$ expression is regulated by miR-92 in breast cancer. Cancer Res. 2010, 70, 4778-4784. [CrossRef]

39. Suzuki, F.; Akahira, J.; Miura, I.; Suzuki, T.; Ito, K.; Hayashi, S.; Sasano, H.; Yaegashi, N. Loss of estrogen receptor beta isoform expression and its correlation with aberrant DNA methylation of the $5^{\prime}$-untranslated region in human epithelial ovarian carcinoma. Cancer Sci. 2008, 99, 2365-2372. [CrossRef]

40. Hinnebusch, A.G.; Ivanov, I.P.; Sonenberg, N. Translational control by 5'-untranslated regions of eukaryotic mRNAs. Science 2016, 352, 1413-1416. [CrossRef]

41. Thomas, C.; Gustafsson, J.A. The different roles of ER subtypes in cancer biology and therapy. Nat. Rev. Cancer 2011, 11, 597-608. [CrossRef]

42. Kampa, M.; Pelekanou, V.; Notas, G.; Stathopoulos, E.N.; Castanas, E. The estrogen receptor: Two or more molecules, multiple variants, diverse localizations, signaling and functions. Are we undergoing a paradigm-shift as regards their significance in breast cancer? Hormones 2013, 12, 69-85. [CrossRef]

43. Hewitt, S.C.; Korach, K.S. Estrogen Receptors: New Directions in the New Millennium. Endocr. Rev. 2018, 39, 664-675. [CrossRef] 
44. Fuentes, N.; Silveyra, P. Estrogen receptor signaling.g mechanisms. Adv. Protein Chem. Struct. Biol. 2019, 116, 135-170.

45. Leung, Y.K.; Ho, S.M. Estrogen receptor beta: Switching to a new partner and escaping from estrogen. Sci. Signal. 2011, 4, pe19. [CrossRef] [PubMed]

46. McDonnell, D.P.; Norris, J.D. Connections and regulation of the human estrogen receptor. Science 2002, 296, 1642-1644. [CrossRef]

47. Le Romancer, M.; Poulard, C.; Cohen, P.; Sentis, S.; Renoir, J.M.; Corbo, L. Cracking the estrogen receptor's posttranslational code in breast tumors. Endocr. Rev. 2011, 32, 597-622. [CrossRef] [PubMed]

48. Mal, R.; Magner, A.; David, J.; Datta, J.; Vallabhaneni, M.; Kassem, M.; Manouchehri, J.; Willingham, N.; Stover, D.; Vandeusen, J.; et al. Estrogen Receptor Beta (ERbeta): A Ligand Activated Tumor Suppressor. Front. Oncol. 2020, 10, 587386. [CrossRef]

49. Pinceti, E.; Shults, C.L.; Rao, Y.S.; Mott, N.N.; Pak, T.R. Phosphorylation Alters Oestrogen Receptor beta-Mediated Transcription in Neurones. J. Neuroendocrinol. 2015, 27, 861-871. [CrossRef] [PubMed]

50. Chang, E.C.; Charn, T.H.; Park, S.H.; Helferich, W.G.; Komm, B.; Katzenellenbogen, J.A.; Katzenellenbogen, B.S. Estrogen Receptors alpha and beta as determinants of gene expression: Influence of ligand, dose, and chromatin binding. Mol. Endocrinol. 2008, 22, 1032-1043. [CrossRef] [PubMed]

51. Williams, C.; Edvardsson, K.; Lewandowski, S.A.; Strom, A.; Gustafsson, J.A. A genome-wide study of the repressive effects of estrogen receptor beta on estrogen receptor alpha signaling in breast cancer cells. Oncogene 2008, 27, 1019-1032. [CrossRef]

52. Vivar, O.I.; Zhao, X.; Saunier, E.F.; Griffin, C.; Mayba, O.S.; Tagliaferri, M.; Cohen, I.; Speed, T.P.; Leitman, D.C. Estrogen receptor beta binds to and regulates three distinct classes of target genes. J. Biol. Chem. 2010, 285, 22059-22066. [CrossRef]

53. O'Lone, R.; Frith, M.C.; Karlsson, E.K.; Hansen, U. Genomic targets of nuclear estrogen receptors. Mol. Endocrinol. 2004, 18, 1859-1875. [CrossRef]

54. Zhao, C.; Gao, H.; Liu, Y.; Papoutsi, Z.; Jaffrey, S.; Gustafsson, J.A.; Dahlman-Wright, K. Genome-wide mapping of estrogen receptor-beta-binding regions reveals extensive cross-talk with transcription factor activator protein-1. Cancer Res. 2010, 70, 5174-5183. [CrossRef]

55. Paech, K.; Webb, P.; Kuiper, G.G.; Nilsson, S.; Gustafsson, J.; Kushner, P.J.; Scanlan, T.S. Differential ligand activation of estrogen receptors ERalpha and ERbeta at AP1 sites. Science 1997, 277, 1508-1510. [CrossRef]

56. De Bosscher, K.; Vanden Berghe, W.; Haegeman, G. Cross-talk between nuclear receptors and nuclear factor kappaB. Oncogene 2006, 25, 6868-6886. [CrossRef]

57. Richards, J.S. Perspective: The ovarian follicle-A perspective in 2001. Endocrinology 2001, 142, 2184-2193. [CrossRef] [PubMed]

58. Baerwald, A.R.; Adams, G.P.; Pierson, R.A. Ovarian antral folliculogenesis during the human menstrual cycle: A review. Hum. Reprod. Update 2012, 18, 73-91. [CrossRef] [PubMed]

59. Drummond, A.E.; Fuller, P.J. The importance of ERbeta signalling in the ovary. J. Endocrinol. 2010, 205, 15-23. [CrossRef]

60. Hamilton, K.J.; Hewitt, S.C.; Arao, Y.; Korach, K.S. Estrogen Hormone Biology. Curr Top. Dev. Biol. 2017, 125, 109-146. [PubMed]

61. Khristi, V.; Chakravarthi, V.P.; Singh, P.; Ghosh, S.; Pramanik, A.; Ratri, A.; Borosha, S.; Roby, K.F.; Wolfe, M.W.; Rumi, M.A.K. ESR2 regulates granulosa cell genes essential for follicle maturation and ovulation. Mol. Cell Endocrinol. 2018, 474, 214-226. [CrossRef]

62. Emmen, J.M.; Couse, J.F.; Elmore, S.A.; Yates, M.M.; Kissling, G.E.; Korach, K.S. In vitro growth and ovulation of follicles from ovaries of estrogen receptor (ER) $\alpha$ and ER $\beta$ null mice indicate a role for ER $\{$ beta $\}$ in follicular maturation. Endocrinology 2005, 146, 2817-2826. [CrossRef] [PubMed]

63. Billig, H.; Furuta, I.; Hsueh, A.J. Estrogens inhibit and androgens enhance ovarian granulosa cell apoptosis. Endocrinology 1993, 133, 2204-2212. [CrossRef]

64. Quirk, S.M.; Cowan, R.G.; Harman, R.M. The susceptibility of granulosa cells to apoptosis is influenced by oestradiol and the cell cycle. J. Endocrinol. 2006, 189, 441-453. [CrossRef] [PubMed]

65. Robker, R.L.; Richards, J.S. Hormonal control of the cell cycle in ovarian cells: Proliferation versus differentiation. Biol. Reprod. 1998, 59, 476-482. [CrossRef] [PubMed]

66. Archer, D.F.; Zeleznik, A.J.; Rockette, H.E. Ovarian follicular maturation in women. II. Reversal of estrogen inhibited ovarian folliculogenesis by human gonadotropin. Fertil Steril 1988, 50, 555-561. [CrossRef]

67. Treeck, O.; Pfeiler, G.; Mitter, D.; Lattrich, C.; Piendl, G.; Ortmann, O. Estrogen receptor \{beta\}1 exerts antitumoral effects on SK-OV-3 ovarian cancer cells. J. Endocrinol. 2007, 193, 421-433. [CrossRef]

68. Dey, P.; Jonsson, P.; Hartman, J.; Williams, C.; Strom, A.; Gustafsson, J.A. Estrogen receptors beta1 and beta2 have opposing roles in regulating proliferation and bone metastasis genes in the prostate cancer cell line PC3. Mol. Endocrinol. 2012, 26, 1991-2003. [CrossRef]

69. Guillette, T.C.; Jackson, T.W.; Belcher, S.M. Duality of estrogen receptor beta action in cancer progression. Curr. Opin. Pharmacol. 2018, 41, 66-73. [CrossRef] [PubMed]

70. Piperigkou, Z.; Bouris, P.; Onisto, M.; Franchi, M.; Kletsas, D.; Theocharis, A.D.; Karamanos, N.K. Estrogen receptor beta modulates breast cancer cells functional properties, signaling and expression of matrix molecules. Matrix Biol. 2016, 56, 4-23. [CrossRef]

71. Liu, J.; Sareddy, G.R.; Zhou, M.; Viswanadhapalli, S.; Li, X.; Lai, Z.; Tekmal, R.R.; Brenner, A.J.; Vadlamudi, R.K. Differential effects of estrogen receptor beta isoforms on glioblastoma progression. Cancer Res. 2018, 72, 3176-3189. [CrossRef] [PubMed] 
72. Sundarrajan, C.; Liao, W.X.; Roy, A.C.; Ng, S.C. Association between estrogen receptor-beta gene polymorphisms and ovulatory dysfunctions in patients with menstrual disorders. J. Clin. Endocrinol. Metab. 2001, 86, 135-139.

73. Robert, F.; Pelletier, J. Exploring the Impact of Single-Nucleotide Polymorphisms on Translation. Front. Genet. 2018, 9, 507. [CrossRef]

74. Lang-Muritano, M.; Sproll, P.; Wyss, S.; Kolly, A.; Hurlimann, R.; Konrad, D.; Biason-Lauber, A. Early-Onset Complete Ovarian Failure and Lack of Puberty in a Woman with Mutated Estrogen Receptor beta (ESR2). J. Clin. Endocrinol. Metab. 2018, 103, 3748-3756. [CrossRef]

75. Asadi, M.; Ghafouri-Fard, S.; Zare-Abdollahi, D.; Ebrahim-Habibi, A.; Matin, N. Estrogen receptor mutation in a girl with primary amenorrhea. Clin. Genet. 2013, 83, 497-498. [CrossRef] [PubMed]

76. Baetens, D.; Guran, T.; Mendonca, B.B.; Gomes, N.L.; De Cauwer, L.; Peelman, F.; Verdin, H.; Vuylsteke, M.; Van der Linden, M.; Esr2 Study, G.; et al. Biallelic and monoallelic ESR2 variants associated with 46,XY disorders of sex development. Genet. Med. 2018, 20, 717-727. [CrossRef]

77. Wolf, W.M.; Wattick, R.A.; Kinkade, O.N.; Olfert, M.D. Geographical Prevalence of Polycystic Ovary Syndrome as Determined by Region and Race/Ethnicity. Int. J. Environ. Res. Public Health 2018, 15, 2589. [CrossRef] [PubMed]

78. Franks, S.; Stark, J.; Hardy, K. Follicle dynamics and anovulation in polycystic ovary syndrome. Hum. Reprod Update 2008, 14, 367-378. [CrossRef]

79. Taylor, A.E.; McCourt, B.; Martin, K.A.; Anderson, E.J.; Adams, J.M.; Schoenfeld, D.; Hall, J.E. Determinants of abnormal gonadotropin secretion in clinically defined women with polycystic ovary syndrome. J. Clin. Endocrinol. Metab. 1997, 82, 2248-2256. [CrossRef] [PubMed]

80. McCartney, C.R.; Eagleson, C.A.; Marshall, J.C. Regulation of gonadotropin secretion: Implications for polycystic ovary syndrome. Semin Reprod. Med. 2002, 20, 317-326. [CrossRef]

81. Ambekar, A.S.; Kelkar, D.S.; Pinto, S.M.; Sharma, R.; Hinduja, I.; Zaveri, K.; Pandey, A.; Prasad, T.S.; Gowda, H.; Mukherjee, S. Proteomics of follicular fluid from women with polycystic ovary syndrome suggests molecular defects in follicular development. J. Clin. Endocrinol. Metab. 2015, 100, 744-753. [CrossRef]

82. Domingues, T.S.; Bonetti, T.C.; Pimenta, D.C.; Mariano, D.O.C.; Barros, B.; Aquino, A.P.; Motta, E.L.A. Proteomic profile of follicular fluid from patients with polycystic ovary syndrome (PCOS) submitted to in vitro fertilization (IVF) compared to oocyte donors. JBRA Assist. Reprod. 2019, 23, 367-391. [CrossRef]

83. Yu, K.; Wang, R.X.; Li, M.H.; Sun, T.C.; Zhou, Y.W.; Li, Y.Y.; Sun, L.H.; Zhang, B.L.; Lian, Z.X.; Xue, S.G.; et al. Melatonin Reduces Androgen Production and Upregulates Heme Oxygenase-1 Expression in Granulosa Cells from PCOS Patients with Hypoestrogenia and Hyperandrogenia. Oxid Med. Cell Longev 2019, 2019, 8218650. [CrossRef]

84. Naessen, T.; Kushnir, M.M.; Chaika, A.; Nosenko, J.; Mogilevkina, I.; Rockwood, A.L.; Carlstrom, K.; Bergquist, J.; Kirilovas, D. Steroid profiles in ovarian follicular fluid in women with and without polycystic ovary syndrome, analyzed by liquid chromatography-tandem mass spectrometry. Fertil Steril 2010, 94, 2228-2233. [CrossRef] [PubMed]

85. Eden, J.A.; Jones, J.; Carter, G.D.; Alaghband-Zadeh, J. Follicular fluid concentrations of insulin-like growth factor 1, epidermal growth factor, transforming growth factor-alpha and sex-steroids in volume matched normal and polycystic human follicles. Clin. Endocrinol. 1990, 32, 395-405. [CrossRef]

86. Agarwal, S.K.; Judd, H.L.; Magoffin, D.A. A mechanism for the suppression of estrogen production in polycystic ovary syndrome. J. Clin. Endocrinol. Metab. 1996, 81, 3686-3691. [PubMed]

87. Dewailly, D.; Robin, G.; Peigne, M.; Decanter, C.; Pigny, P.; Catteau-Jonard, S. Interactions between androgens, FSH, anti-Mullerian hormone and estradiol during folliculogenesis in the human normal and polycystic ovary. Hum. Reprod Update 2016, 22, 709-724. [CrossRef]

88. Rizza, P.; Barone, I.; Zito, D.; Giordano, F.; Lanzino, M.; De Amicis, F.; Mauro, L.; Sisci, D.; Catalano, S.; Dahlman Wright, K.; et al. Estrogen receptor beta as a novel target of androgen receptor action in breast cancer cell lines. Breast Cancer Res. 2014, 16, R21. [CrossRef] [PubMed]

89. Gervasio, C.G.; Bernuci, M.P.; Silva-de-Sa, M.F.; Rosa, E.S.A.C. The role of androgen hormones in early follicular development. ISRN Obstet Gynecol. 2014, 2014, 818010. [CrossRef]

90. Yang, F.; Ruan, Y.C.; Yang, Y.J.; Wang, K.; Liang, S.S.; Han, Y.B.; Teng, X.M.; Yang, J.Z. Follicular hyperandrogenism downregulates aromatase in luteinized granulosa cells in polycystic ovary syndrome women. Reproduction 2015, 150, 289-296. [CrossRef]

91. Owens, L.A.; Kristensen, S.G.; Lerner, A.; Christopoulos, G.; Lavery, S.; Hanyaloglu, A.C.; Hardy, K.; Yding Andersen, C.; Franks, S. Gene Expression in Granulosa Cells from Small Antral Follicles from Women with or without Polycystic Ovaries. J. Clin. Endocrinol. Metab. 2019, 104, 6182-6192. [CrossRef]

92. Jakimiuk, A.J.; Weitsman, S.R.; Brzechffa, P.R.; Magoffin, D.A. Aromatase mRNA expression in individual follicles from polycystic ovaries. Mol. Hum. Reprod. 1998, 4, 1-8. [CrossRef]

93. Lerner, A.; Owens, L.A.; Coates, M.; Simpson, C.; Poole, G.; Velupillai, J.; Liyanage, M.; Christopoulos, G.; Lavery, S.; Hardy, K. Expression of genes controlling steroid metabolism and action in granulosa-lutein cells of women with polycystic ovaries. Mol. Cell Endocrinol. 2019, 486, 47-54. [CrossRef]

94. Yu, Y.Y.; Sun, C.X.; Liu, Y.K.; Li, Y.; Wang, L.; Zhang, W. Promoter methylation of CYP19A1 gene in Chinese polycystic ovary syndrome patients. Gynecol. Obstet Invest. 2013, 76, 209-213. [CrossRef] 
95. Hosseini, E.; Shahhoseini, M.; Afsharian, P.; Karimian, L.; Ashrafi, M.; Mehraein, F.; Afatoonian, R. Role of epigenetic modifications in the aberrant CYP19A1 gene expression in polycystic ovary syndrome. Arch. Med. Sci. 2019, 15, 887-895. [CrossRef] [PubMed]

96. Catteau-Jonard, S.; Jamin, S.P.; Leclerc, A.; Gonzales, J.; Dewailly, D.; di Clemente, N. Anti-Mullerian hormone, its receptor, FSH receptor, and androgen receptor genes are overexpressed by granulosa cells from stimulated follicles in women with polycystic ovary syndrome. J. Clin. Endocrinol. Metab. 2008, 93, 4456-4461. [CrossRef]

97. Willis, D.S.; Watson, H.; Mason, H.D.; Galea, R.; Brincat, M.; Franks, S. Premature response to luteinizing hormone of granulosa cells from anovulatory women with polycystic ovary syndrome: Relevance to mechanism of anovulation. J. Clin. Endocrinol. Metab. 1998, 83, 3984-3991. [CrossRef]

98. Zang, L.; Zhang, Q.; Zhou, Y.; Zhao, Y.; Lu, L.; Jiang, Z.; Peng, Z.; Zou, S. Expression pattern of G proteincoupled estrogen receptor 1 (GPER) in human cumulus granulosa cells (CGCs) of patients with PCOS. Syst. Biol. Reprod Med. 2016, 62, 184-191. [CrossRef] [PubMed]

99. Pierre, A.; Taieb, J.; Giton, F.; Grynberg, M.; Touleimat, S.; El Hachem, H.; Fanchin, R.; Monniaux, D.; Cohen-Tannoudji, J.; di Clemente, N. Dysregulation of the Anti-Mullerian Hormone System by Steroids in Women with Polycystic Ovary Syndrome. J. Clin. Endocrinol. Metab. 2017, 102, 3970-3978. [CrossRef]

100. Artimani, T.; Saidijam, M.; Aflatoonian, R.; Amiri, I.; Ashrafi, M.; Shabab, N.; Mohammadpour, N.; Mehdizadeh, M. Estrogen and progesterone receptor subtype expression in granulosa cells from women with polycystic ovary syndrome. Gynecol. Endocrinol. 2015, 31, 379-383. [CrossRef] [PubMed]

101. Guet, P.; Royere, D.; Paris, A.; Lansac, J.; Driancourt, M.A. Aromatase activity of human granulosa cells in vitro: Effects of gonadotrophins and follicular fluid. Hum. Reprod. 1999, 14, 1182-1189. [CrossRef]

102. Kirilovas, D.; Chaika, A.; Bergstrom, M.; Bergstrom-Petterman, E.; Carlstrom, K.; Nosenko, J.; Korniyenko, S.; Yakovets, A.; Mogilevkina, I.; Naessen, T. Granulosa cell aromatase enzyme activity: Effects of follicular fluid from patients with polycystic ovary syndrome, using aromatase conversion and [11C]vorozole-binding assays. Gynecol. Endocrinol. 2006, 22, 685-691. [CrossRef] [PubMed]

103. Liu, X.Y.; Yang, Y.J.; Tang, C.L.; Wang, K.; Chen, J.J.; Teng, X.M.; Ruan, Y.C.; Yang, J.Z. Elevation of antimullerian hormone in women with polycystic ovary syndrome undergoing assisted reproduction: Effect of insulin. Fertil Steril 2019, 111, 157-167. [CrossRef]

104. Volpe, A.; Coukos, G.; D'Ambrogio, G.; Artini, P.G.; Genazzani, A.R. Follicular fluid steroid and epidermal growth factor content, and in vitro estrogen release by granulosa-luteal cells from patients with polycystic ovaries in an IVF/ET program. Eur. J. Obstet Gynecol. Reprod. Biol. 1991, 42, 195-199. [CrossRef]

105. Zhang, T.; Tian, F.; Huo, R.; Tang, A.; Zeng, Y.; Duan, Y.G. Detection of dendritic cells and related cytokines in follicular fluid of patients with polycystic ovary syndrome. Am. J. Reprod. Immunol. 2017, 78, e12717. [CrossRef] [PubMed]

106. Pellatt, L.; Rice, S.; Dilaver, N.; Heshri, A.; Galea, R.; Brincat, M.; Brown, K.; Simpson, E.R.; Mason, H.D. Anti-Mullerian hormone reduces follicle sensitivity to follicle-stimulating hormone in human granulosa cells. Fertil Steril 2011, 96, 1246-1251.e1. [CrossRef]

107. Catteau-Jonard, S.; Pigny, P.; Reyss, A.C.; Decanter, C.; Poncelet, E.; Dewailly, D. Changes in serum anti-mullerian hormone level during low-dose recombinant follicular-stimulating hormone therapy for anovulation in polycystic ovary syndrome. J. Clin. Endocrinol. Metab. 2007, 92, 4138-4143. [CrossRef]

108. Harlow, C.R.; Shaw, H.J.; Hillier, S.G.; Hodges, J.K. Factors influencing follicle-stimulating hormone-responsive steroidogenesis in marmoset granulosa cells: Effects of androgens and the stage of follicular maturity. Endocrinology 1988, 122, 2780-2787. [CrossRef]

109. Salmassi, A.; Lu, S.; Hedderich, J.; Oettinghaus, C.; Jonat, W.; Mettler, L. Interaction of interleukin-6 on human granulosa cell steroid secretion. J. Endocrinol. 2001, 170, 471-478. [CrossRef]

110. Miller, T.W.; Shin, I.; Kagawa, N.; Evans, D.B.; Waterman, M.R.; Arteaga, C.L. Aromatase is phosphorylated in situ at serine-118. J. Steroid Biochem. Mol. Biol. 2008, 112, 95-101. [CrossRef] [PubMed]

111. Welt, C.K.; Taylor, A.E.; Fox, J.; Messerlian, G.M.; Adams, J.M.; Schneyer, A.L. Follicular arrest in polycystic ovary syndrome is associated with deficient inhibin A and B biosynthesis. J. Clin. Endocrinol. Metab. 2005, 90, 5582-5587. [CrossRef]

112. Welt, C.K.; Schneyer, A.L. Differential regulation of inhibin B and inhibin a by follicle-stimulating hormone and local growth factors in human granulosa cells from small antral follicles. J. Clin. Endocrinol. Metab. 2001, 86, 330-336. [CrossRef]

113. Turner, I.M.; Saunders, P.T.; Shimasaki, S.; Hillier, S.G. Regulation of inhibin subunit gene expression by FSH and estradiol in cultured rat granulosa cells. Endocrinology 1989, 125, 2790-2792. [CrossRef] [PubMed]

114. Tamura, K.; Kawaguchi, T.; Hara, T.; Takatoshi, S.; Tohei, A.; Miyajima, A.; Seishi, T.; Kogo, H. Interleukin-6 decreases estrogen production and messenger ribonucleic acid expression encoding aromatase during in vitro cytodifferentiation of rat granulosa cell. Mol. Cell Endocrinol. 2000, 170, 103-111. [CrossRef]

115. Liu, H.; Liu, K.; Bodenner, D.L. Estrogen receptor inhibits interleukin-6 gene expression by disruption of nuclear factor kappaB transactivation. Cytokine 2005, 31, 251-257. [CrossRef] [PubMed]

116. Magoffin, D.A.; Hubert-Leslie, D.; Zachow, R.J. Estradiol-17 beta, insulin-like growth factor-I, and luteinizing hormone inhibit secretion of transforming growth factor beta by rat ovarian theca-interstitial cells. Biol. Reprod. 1995, 53, 627-635. [CrossRef]

117. Magoffin, D.A.; Gancedo, B.; Erickson, G.F. Transforming growth factor-beta promotes differentiation of ovarian thecal-interstitial cells but inhibits androgen production. Endocrinology 1989, 125, 1951-1958. [CrossRef]

118. Zhang, H.; Lu, S.; Xu, R.; Tang, Y.; Liu, J.; Li, C.; Wei, J.; Yao, R.; Zhao, X.; Wei, Q. Mechanisms of Estradiol-induced EGF-like Factor Expression and Oocyte Maturation via G Protein-coupled Estrogen Receptor. Endocrinology 2020, 161, 190. [CrossRef] 
119. Grynberg, M.; Pierre, A.; Rey, R.; Leclerc, A.; Arouche, N.; Hesters, L.; Catteau-Jonard, S.; Frydman, R.; Picard, J.Y.; Fanchin, R. Differential regulation of ovarian anti-mullerian hormone (AMH) by estradiol through alpha- and beta-estrogen receptors. J. Clin. Endocrinol. Metab. 2012, 97, E1649-E1657. [CrossRef]

120. Das, M.; Djahanbakhch, O.; Hacihanefioglu, B.; Saridogan, E.; Ikram, M.; Ghali, L.; Raveendran, M.; Storey, A. Granulosa cell survival and proliferation are altered in polycystic ovary syndrome. J. Clin. Endocrinol. Metab. 2008, 93, 881-887. [CrossRef] [PubMed]

121. Mikaeili, S.; Rashidi, B.H.; Safa, M.; Najafi, A.; Sobhani, A.; Asadi, E.; Abbasi, M. Altered FoxO3 expression and apoptosis in granulosa cells of women with polycystic ovary syndrome. Arch. Gynecol. Obstet 2016, 294, 185-192. [CrossRef]

122. Racine, C.; Genet, C.; Bourgneuf, C.; Dupont, C.; Plisson-Petit, F.; Sarry, J.; Hennequet-Antier, C.; Vigouroux, C.; Mathieu d'Argent, E.; Pierre, A.; et al. New Anti-Mullerian Hormone Target Genes Involved in Granulosa Cell Survival in Women with Polycystic Ovary Syndrome. J. Clin. Endocrinol. Metab. 2021, 106, e1271-e1289. [CrossRef]

123. Jamieson, S.; Fuller, P.J. Molecular pathogenesis of granulosa cell tumors of the ovary. Endocr. Rev. 2012, 33, 109-144. [CrossRef] [PubMed]

124. Fuller, P.J.; Chu, S.; Fikret, S.; Burger, H.G. Molecular pathogenesis of granulosa cell tumours. Mol. Cell Endocrinol. 2002, 191, 89-96. [CrossRef]

125. Cluzet, V.; Devillers, M.M.; Petit, F.; Chauvin, S.; Francois, C.M.; Giton, F.; Genestie, C.; di Clemente, N.; Cohen-Tannoudji, J.; Guigon, C.J. Aberrant granulosa cell-fate related to inactivated p53/Rb signaling contributes to granulosa cell tumors and to FOXL2 downregulation in the mouse ovary. Oncogene 2020, 39, 1875-1890. [CrossRef] [PubMed]

126. Bulun, S.E.; Simpson, E.R. Aromatase expression in women's cancers. Adv. Exp. Med. Biol. 2008, 630, 112-132. [PubMed]

127. Kato, N.; Uchigasaki, S.; Fukase, M.; Kurose, A. Expression of P450 Aromatase in Granulosa Cell Tumors and Sertoli-Stromal Cell Tumors of the Ovary: Which Cells Are Responsible for Estrogenesis? Int. J. Gynecol. Pathol. 2016, 35, 41-47. [CrossRef] [PubMed]

128. Koukourakis, G.V.; Kouloulias, V.E.; Koukourakis, M.J.; Zacharias, G.A.; Papadimitriou, C.; Mystakidou, K.; Pistevou-Gompaki, K.; Kouvaris, J.; Gouliamos, A. Granulosa cell tumor of the ovary: Tumor review. Integr. Cancer Ther. 2008, 7, 204-215. [CrossRef]

129. Farkkila, A.; Koskela, S.; Bryk, S.; Alfthan, H.; Butzow, R.; Leminen, A.; Puistola, U.; Tapanainen, J.S.; Heikinheimo, M.; Anttonen, M.; et al. The clinical utility of serum anti-Mullerian hormone in the follow-up of ovarian adult-type granulosa cell tumors-A comparative study with inhibin B. Int. J. Cancer 2015, 137, 1661-1671. [CrossRef]

130. Shah, S.P.; Kobel, M.; Senz, J.; Morin, R.D.; Clarke, B.A.; Wiegand, K.C.; Leung, G.; Zayed, A.; Mehl, E.; Kalloger, S.E.; et al. Mutation of FOXL2 in granulosa-cell tumors of the ovary. N. Engl. J. Med. 2009, 360, 2719-2729. [CrossRef]

131. Hirano, M.; Wada-Hiraike, O.; Fu, H.; Akino, N.; Isono, W.; Sakurabashi, A.; Fukuda, T.; Morita, Y.; Tanikawa, M.; Miyamoto, Y.; et al. The Emerging Role of FOXL2 in Regulating the Transcriptional Activation Function of Estrogen Receptor beta: An Insight into Ovarian Folliculogenesis. Reprod Sci. 2017, 24, 133-141. [CrossRef]

132. Leung, D.T.H.; Fuller, P.J.; Chu, S. Impact of FOXL2 mutations on signaling in ovarian granulosa cell tumors. Int. J. Biochem. Cell Biol. 2016, 72, 51-54. [CrossRef]

133. Li, J.; Bao, R.; Peng, S.; Zhang, C. The molecular mechanism of ovarian granulosa cell tumors. J. Ovarian Res. 2018, 11, 13. [CrossRef]

134. Heublein, S.; Mayr, D.; Friese, K.; Jarrin-Franco, M.C.; Lenhard, M.; Mayerhofer, A.; Jeschke, U. The G-protein-coupled estrogen receptor (GPER/GPR30) in ovarian granulosa cell tumors. Int. J. Mol. Sci. 2014, 15, 15161-15172. [CrossRef]

135. Francois, C.M.; Wargnier, R.; Petit, F.; Goulvent, T.; Rimokh, R.; Treilleux, I.; Ray-Coquard, I.; Zazzu, V.; Cohen-Tannoudji, J.; Guigon, C.J. 17beta-estradiol inhibits spreading of metastatic cells from granulosa cell tumors through a non-genomic mechanism involving GPER1. Carcinogenesis 2015, 36, 564-573. [CrossRef]

136. Haltia, U.M.; Pihlajoki, M.; Andersson, N.; Makinen, L.; Tapper, J.; Cervera, A.; Horlings, H.M.; Turpeinen, U.; Anttonen, M.; Butzow, R.; et al. Functional Profiling of FSH and Estradiol in Ovarian Granulosa Cell Tumors. J. Endocr. Soc. 2020, 4 , bvaa034. [CrossRef] [PubMed]

137. Staibano, S.; Franco, R.; Mezza, E.; Chieffi, P.; Sinisi, A.; Pasquali, D.; Errico, M.E.; Nappi, C.; Tremolaterra, F.; Somma, P.; et al. Loss of oestrogen receptor beta, high PCNA and p53 expression and aneuploidy as markers of worse prognosis in ovarian granulosa cell tumours. Histopathology 2003, 43, 254-262. [CrossRef]

138. Mills, A.M.; Chinn, Z.; Rauh, L.A.; Dusenbery, A.C.; Whitehair, R.M.; Saks, E.; Duska, L.R. Emerging biomarkers in ovarian granulosa cell tumors. Int. J. Gynecol. Cancer 2019, 29, 560-565. [CrossRef] [PubMed]

139. Hutton, S.M.; Webster, L.R.; Nielsen, S.; Leung, Y.; Stewart, C.J. Immunohistochemical expression and prognostic significance of oestrogen receptor-alpha, oestrogen receptor-beta, and progesterone receptor in stage 1 adult-type granulosa cell tumour of the ovary. Pathology 2012, 44, 611-616. [CrossRef] [PubMed]

140. Farinola, M.A.; Gown, A.M.; Judson, K.; Ronnett, B.M.; Barry, T.S.; Movahedi-Lankarani, S.; Vang, R. Estrogen receptor alpha and progesterone receptor expression in ovarian adult granulosa cell tumors and Sertoli-Leydig cell tumors. Int. J. Gynecol. Pathol. 2007, 26, 375-382. [CrossRef] [PubMed]

141. Puechl, A.M.; Edwards, J.; Suri, A.; Nakayama, J.; Bean, S.; Gehrig, P.; Saks, E.; Duska, L.; Broadwater, G.; Ehrisman, J.; et al. The association between progesterone receptor expression and survival in women with adult granulosa cell tumors. Gynecol. Oncol. 2019, 153, 74-79. [CrossRef] 
142. Cluzet, V.; Devillers, M.M.; Petit, F.; Pierre, A.; Giton, F.; Airaud, E.; L’Hôte, D.; Leary, A.; Genestie, C.; Treilleux, I.; et al. Estradiol promotes cell survival and induces Greb1 expression in granulosa cell tumors of the ovary through an ER $\alpha$-dependent mechanism. J. Pathol. 2021, in press. [CrossRef]

143. Nelson, A.W.; Groen, A.J.; Miller, J.L.; Warren, A.Y.; Holmes, K.A.; Tarulli, G.A.; Tilley, W.D.; Katzenellenbogen, B.S.; Hawse, J.R.; Gnanapragasam, V.J.; et al. Comprehensive assessment of estrogen receptor beta antibodies in cancer cell line models and tissue reveals critical limitations in reagent specificity. Mol. Cell Endocrinol. 2017, 440, 138-150. [CrossRef]

144. Yoo, N.J.; Kim, M.S.; Lee, S.H. Expression and mutation analyses of Fas, FLIP and Bcl-2 in granulosa cell tumor of ovary. Tumori 2012, 98, 118e-121e. [CrossRef]

145. Yager, J.D.; Chen, J.Q. Mitochondrial estrogen receptors-new insights into specific functions. Trends Endocrinol. Metab. 2007, 18, 89-91. [CrossRef] [PubMed]

146. Klinge, C.M. Estrogenic control of mitochondrial function. Redox Biol. 2020, 31, 101435. [CrossRef]

147. van Meurs, H.S.; van der Velden, J.; Buist, M.R.; van Driel, W.J.; Kenter, G.G.; van Lonkhuijzen, L.R. Evaluation of response to hormone therapy in patients with measurable adult granulosa cell tumors of the ovary. Acta Obstet. Gynecol. Scand. 2015, 94, 1269-1275. [CrossRef] [PubMed]

148. Chu, S.; Nishi, Y.; Yanase, T.; Nawata, H.; Fuller, P.J. Transrepression of estrogen receptor beta signaling by nuclear factor-kappab in ovarian granulosa cells. Mol. Endocrinol. 2004, 18, 1919-1928. [CrossRef]

149. Chaurasiya, S.; Widmann, S.; Botero, C.; Lin, C.Y.; Gustafsson, J.A.; Strom, A.M. Estrogen receptor beta exerts tumor suppressive effects in prostate cancer through repression of androgen receptor activity. PLoS ONE 2020, 15, e0226057. [CrossRef] [PubMed]

150. Bossard, C.; Busson, M.; Vindrieux, D.; Gaudin, F.; Machelon, V.; Brigitte, M.; Jacquard, C.; Pillon, A.; Balaguer, P.; Balabanian, K.; et al. Potential role of estrogen receptor beta as a tumor suppressor of epithelial ovarian cancer. PLoS ONE 2012, 7, e44787.

151. Mandusic, V.; Dimitrijevic, B.; Nikolic-Vukosavljevic, D.; Neskovic-Konstantinovic, Z.; Kanjer, K.; Hamann, U. Different associations of estrogen receptor beta isoforms, ERbeta1 and ERbeta2, expression levels with tumor size and survival in earlyand late-onset breast cancer. Cancer Lett. 2012, 321, 73-79. [CrossRef]

152. Poola, I.; Fuqua, S.A.; De Witty, R.L.; Abraham, J.; Marshallack, J.J.; Liu, A. Estrogen receptor alpha-negative breast cancer tissues express significant levels of estrogen-independent transcription factors, ERbeta1 and ERbeta5: Potential molecular targets for chemoprevention. Clin. Cancer Res. 2005, 11, 7579-7585. [CrossRef] [PubMed]

153. De Stefano, I.; Zannoni, G.F.; Prisco, M.G.; Fagotti, A.; Tortorella, L.; Vizzielli, G.; Mencaglia, L.; Scambia, G.; Gallo, D. Cytoplasmic expression of estrogen receptor beta (ERbeta) predicts poor clinical outcome in advanced serous ovarian cancer. Gynecol. Oncol. 2011, 122, 573-579. [CrossRef] [PubMed]

154. van Kruchten, M.; van der Marel, P.; de Munck, L.; Hollema, H.; Arts, H.; Timmer-Bosscha, H.; de Vries, E.; Hospers, G.; Reyners, A. Hormone receptors as a marker of poor survival in epithelial ovarian cancer. Gynecol. Oncol. 2015, 138, 634-639. [CrossRef] [PubMed]

155. Schuler-Toprak, S.; Weber, F.; Skrzypczak, M.; Ortmann, O.; Treeck, O. Estrogen receptor beta is associated with expression of cancer associated genes and survival in ovarian cancer. BMC Cancer 2018, 18, 981. [CrossRef] [PubMed]

156. Leung, Y.K.; Lam, H.M.; Wu, S.; Song, D.; Levin, L.; Cheng, L.; Wu, C.L.; Ho, S.M. Estrogen receptor beta2 and beta5 are associated with poor prognosis in prostate cancer, and promote cancer cell migration and invasion. Endocr. Relat Cancer 2010, 17, 675-689. [CrossRef] [PubMed]

157. Faria, M.; Shepherd, P.; Pan, Y.; Chatterjee, S.S.; Navone, N.; Gustafsson, J.A.; Strom, A. The estrogen receptor variants beta2 and beta5 induce stem cell characteristics and chemotherapy resistance in prostate cancer through activation of hypoxic signaling. Oncotarget 2018, 9, 36273-36288. [CrossRef]

158. Yan, M.; Rayoo, M.; Takano, E.A.; kConFab, I.; Fox, S.B. Nuclear and cytoplasmic expressions of ERbeta1 and ERbeta2 are predictive of response to therapy and alters prognosis in familial breast cancers. Breast Cancer Res. Treat. 2011, 126, 395-405. [CrossRef]

159. Shaaban, A.M.; Green, A.R.; Karthik, S.; Alizadeh, Y.; Hughes, T.A.; Harkins, L.; Ellis, I.O.; Robertson, J.F.; Paish, E.C.; Saunders, P.T.; et al. Nuclear and cytoplasmic expression of ERbeta1, ERbeta2, and ERbeta5 identifies distinct prognostic outcome for breast cancer patients. Clin. Cancer Res. 2008, 14, 5228-5235. [CrossRef]

160. Truong, T.H.; Lange, C.A. Deciphering Steroid Receptor Crosstalk in Hormone-Driven Cancers. Endocrinology 2018, 159, 3897-3907. [CrossRef]

161. Tarallo, R.; Giurato, G.; Bruno, G.; Ravo, M.; Rizzo, F.; Salvati, A.; Ricciardi, L.; Marchese, G.; Cordella, A.; Rocco, T.; et al. The nuclear receptor ERbeta engages AGO2 in regulation of gene transcription, RNA splicing and RISC loading. Genome Biol. 2017, 18, 189. [CrossRef]

162. Jiang, Y.; Gong, P.; Madak-Erdogan, Z.; Martin, T.; Jeyakumar, M.; Carlson, K.; Khan, I.; Smillie, T.J.; Chittiboyina, A.G.; Rotte, S.C.; et al. Mechanisms enforcing the estrogen receptor beta selectivity of botanical estrogens. FASEB J. 2013, 27, 4406-4418. [CrossRef]

163. Liu, J.; Viswanadhapalli, S.; Garcia, L.; Zhou, M.; Nair, B.C.; Kost, E.; Rao Tekmal, R.; Li, R.; Rao, M.K.; Curiel, T.; et al. Therapeutic utility of natural estrogen receptor beta agonists on ovarian cancer. Oncotarget 2017, 8, 50002-50014. [CrossRef] [PubMed] 
164. Gong, P.; Madak-Erdogan, Z.; Li, J.; Cheng, J.; Greenlief, C.M.; Helferich, W.; Katzenellenbogen, J.A.; Katzenellenbogen, B.S. Transcriptomic analysis identifies gene networks regulated by estrogen receptor alpha (ERalpha) and ERbeta that control distinct effects of different botanical estrogens. Nucl. Recept Signal. 2014, 12, e001. [CrossRef]

165. Paweletz, N.; Knierim, M. Tumor-related angiogenesis. Crit. Rev. Oncol. Hematol. 1989, 9, 197-242. [CrossRef]

166. Hartman, J.; Lindberg, K.; Morani, A.; Inzunza, J.; Strom, A.; Gustafsson, J.A. Estrogen receptor beta inhibits angiogenesis and growth of T47D breast cancer xenografts. Cancer Res. 2006, 66, 11207-11213. [CrossRef] [PubMed]

167. Zaitseva, M.; Yue, D.S.; Katzenellenbogen, J.A.; Rogers, P.A.; Gargett, C.E. Estrogen receptor-alpha agonists promote angiogenesis in human myometrial microvascular endothelial cells. J. Soc. Gynecol. Investig. 2004, 11, 529-535. [CrossRef] 